Report

\title{
Radiolarians from Jurassic accretionary complex of the Ashio belt in the Kiryu and Ashikaga District (Quadrangle series 1:50,000), central Japan
}

\author{
ITO Tsuyoshi ${ }^{1, *}$
}

\begin{abstract}
ITO Tsuyoshi (2021) Radiolarians from Jurassic accretionary complex of the Ashio belt in the Kiryu and Ashikaga District (Quadrangle series 1:50,000), central Japan. Bulletin of the Geological Survey of Japan, vol. 72 (4), p. 287-324, 16 figs.
\end{abstract}

\begin{abstract}
Jurassic accretionary complex of the Ashio belt is distributed in the Ashio Mountains, central Japan. The Jurassic accretionary complex is composed of the Kurohone-Kiryu, Omama, Kuzu and Gyodosan complexes. This article presents new radiolarian occurrences from 42 samples of the Jurassic accretionary complex in the Kiryu and Ashikaga District (Quadrangle series 1:50,000). Permian radiolarians occurred in nine chert samples of the Gyodosan Complex. Triassic radiolarians were obtained from four chert samples of the Kuzu Complex. Jurassic radiolarians occurred in one siliceous mudstone sample of the Kurohone-Kiryu Complex; two chert, four siliceous mudstone and two mudstone samples of the Kuzu Complex; and one mudstone sample of the Gyodosan Complex. In addition, the fossil occurrences and their ages are compiled by present and previous studies on the Jurassic accretionary complex in the Ashio Mountains. On that basis, the ocean plate stratigraphy of each complex is reconstructed.
\end{abstract}

Keywords: radiolarian, Ashio belt, Jurassic accretionary complex, Ashio Mountains, ocean plate stratigraphy, Tochigi Prefecture, Gunma Prefecture, central Japan

\section{Introduction}

Jurassic accretionary complex of the Ashio belt is widely exposed in the Ashio Mountains, central Japan (Fig. 1). Geological studies on the Jurassic accretionary complex of the Ashio Mountains began in the late $19^{\text {th }}$ century (e.g. Harada, 1886; Suzuki, 1898a, b). First reports of radiolarians were described from the "slate" of the Ashio Copper Mine by Suzuki (1898a, b). Thereafter, radiolarian occurrences were rarely reported from the Jurassic accretionary complex in the Ashio Mountains until the 1970s. Since the 1980s, reports of radiolarians increased from the Jurassic accretionary complex in the Ashio Mountains. Abundant radiolarian occurrences have been reported from the Tochigi District (e.g. Aono, 1985; Arakawa, 1986, 1997, 1998; Kamata, 1995, 1996, 1997a, b, 1999, 2000; Isogawa et al., 1998; Ootaka et al., 1998; Suzuki et al., 2002), whereas fewer occurrences have been reported from the Kiryu and Ashikaga District (Masuda, 1989; Hayashi et al., 1990; Kamata, 1996; Takayanagi et al., 2001; Motoki and Sashida, 2004).

The author has surveyed the Jurassic accretionary complex in the Kiryu and Ashikaga District for making a geological map, and recently reported radiolarian occurrences from the district (e.g. Ito, 2019, 2020a, b). This article is an additional report of Permian, Triassic and Jurassic radiolarian occurrences from the Jurassic accretionary complex in the district. Further, fossil occurrences from the Jurassic accretionary complex (including neighbor districts) are compiled by the present and previous studies. On that basis, the author attempts to reconstruct the ocean plate stratigraphy of each complex of the Jurassic accretionary complex.

\section{Geologic outline of the Jurassic accretionary complex in the Ashio Mountains}

In the 1960-1980s, Mesozoic conodonts and radiolarians were discovered in the Jurassic accretionary complex in the Ashio Mountains (e.g. Hayashi, 1963, 1968a, b; Koike et al., 1970, 1971; Hayashi and Hasegawa, 1981; Sashida et al., 1982a, b). Kamata (1996) divided the Jurassic accretionary complex in the southern Ashio Mountains into three tectonostratigraphic units, namely the Kurohone-Kiryu, Omama and Kuzu complexes based on geological scheme of accretionary complex. Recently, Ito (2021) identified the Gyodosan Complex, which thrusts over the Kuzu Complex.

The Kurohone-Kiryu Complex, presenting broken to coherent facies, consists mainly of mudstone and chert and moderate amounts of siliceous claystone, with small amounts of basaltic rocks, carbonate rocks, siliceous

\footnotetext{
${ }^{1}$ AIST, Geological Survey of Japan, Research Institute of Geology and Geoinformation

* Corresponding author: ITO, T., Central 7, 1-1-1 Higashi, Tsukuba, Ibaraki 305-8567, Japan. Email: ito-t@aist.go.jp
} 


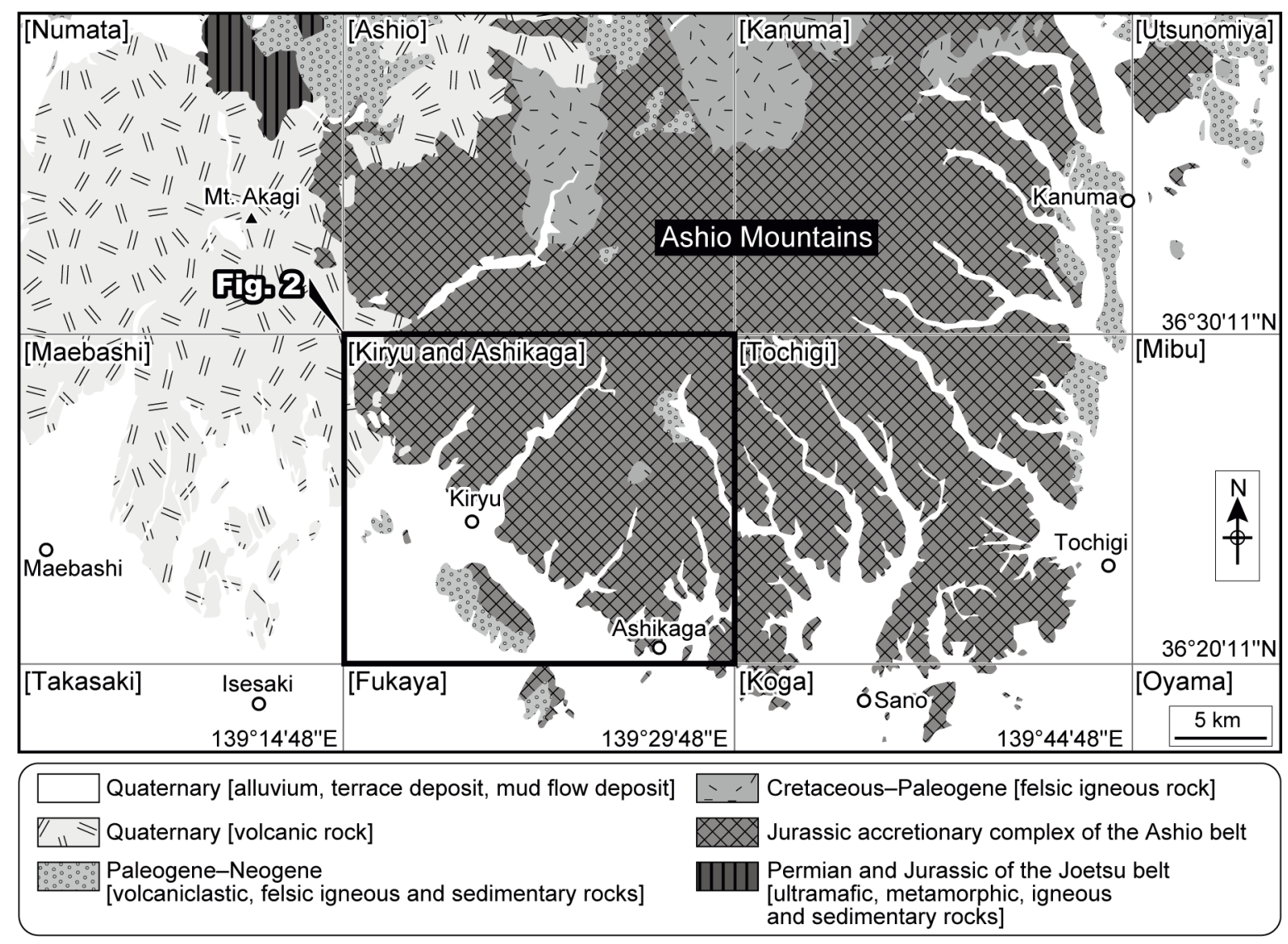

Fig. 1 Index and simplified geologic maps of the Ashio Mountains (modified after from Sudo et al., 1991; Geological Survey of Japan, AIST, 2018). The geographical names in brackets indicate 1:50,000 topographic maps published by the Geospatial Information Authority of Japan.

mudstone, sandstone and pelitic mixed rock. This complex is composed of the upper and lower parts. The upper part is characterized by dominant of mudstone and small amounts of siliceous claystone, compared with the lower part. The upper part contains pelitic mixed rock including blocks of chert and sandstone.

The Omama Complex, presenting broken to mélange facies, mainly comprises basaltic rocks, chert and mudstone, with small amounts of carbonate rocks, siliceous mudstone, sandstone and pelitic mixed rock. This complex is composed of the upper and lower parts. The lower part is characterized by dominant of basaltic rocks and chert, whereas the upper part is composed mainly of pelitic mixed rock including blocks of basaltic rocks, carbonate rocks, chert and sandstone.

The Kuzu Complex comprises three units, namely units 1, 2 and 3. Units 1 and 3, presenting coherent facies, are composed of chert, siliceous mudstone, mudstone, alternations of sandstone and mudstone and sandstone. In addition, Unit 3 includes small amounts of basaltic rocks and carbonate rocks. Unit 2 is composed of basaltic rocks and carbonate rocks with conglomerate, siliceous mudstone and mudstone.

The Gyodosan Complex presents mélange facies. It consists mainly of pelitic mixed rock and chert, with siliceous mudstone, mudstone and sandstone.

\section{Materials and methods}

In total, 321 samples including the author's previous studies (Ito, 2019, 2020a, b; Ito and Nakamura, 2021) underwent the following method to extract radiolarian fossils. The samples, crushed into approximately $1-\mathrm{cm}$ fragments, were soaked in 5\% hydrofluoric acid at room temperature (ca. $20-25^{\circ} \mathrm{C}$ ). Approximately $24 \mathrm{~h}$ later, the residues were collected by a sieve with a mesh diameter of $0.054 \mathrm{~mm}$. Part of the residues were enclosed within a slide prepared with a photocrosslinkable mounting medium (GJ-4006, Gluelabo Ltd.). The slides were analyzed using a transmitted light microscope and then photographed. Several specimens from the residues were mounted on stubs and photographed using scanning electron microscopy.

\section{New radiolarian occurrences from the Kiryu and Ashikaga District}

This article reports new radiolarians occurrences from 
42 samples. Of these, nine samples yielded Permian radiolarians and four samples yielded Triassic ones. Eight samples yielded Jurassic radiolarians. Specimens of undetermined age occurred in 19 samples. Figure 2 show the localities of radiolarian occurrences in the Kiryu and Ashikaga District by the present and previous studies.

\section{1 Permian radiolarians}

Figure 3 is a traverse map including the Hachioji section studied by Ito (2020a) along a hiking trail in the southwest of Mt. Karasawa of the Hachioji Hills. Permian radiolarians were obtained from chert of the Gyodosan Complex (Fig. 4).

The red chert sample (IT19120902) and gray chert sample (IT19120905) yielded Pseudoalbaillella japonica Nestell and Nestell (Figs. 4.2-4.6, 4.8, 4.9, 4.27, 4.28, 4.31-34) and Pseudoalbaillella postscalprata Ishiga (Figs. 4.7, 4.29, 4.30). According to Unitary Association Zones (UAZ) of the Permian proposed by Xiao et al. (2018), the co-occurrence of Pseudoalbaillella japonica and Pseudoalbaillella postscalprata indicates that the average of the statistical likelihood is the highest at UAZ 6 (Kungurian, Cisuralian).

The gray chert sample (IT19120908) yielded Parafollicucullus sp. cf. P. monacanthus (Ishiga and Imoto) (Fig. 4.44). According to the occurrence range of Zhang et al. (2014), Parafollicucullus monacanthus occurred in the Parafollicucullus monacanthus Interval Zone-lower Follicucullus porrectus Interval Zone (upper Wordian-lower Capitanian, Guadalupian).

The gray chert sample (IT19120910) yielded Ishigaconus scholasticus (Ormiston and Babcock) (Fig.4.50) in addition to the short form of Parafollicucullus monacanthus (Figs. 4.46-4.49). According to Zhang et al. (2014), the co-occurrence range of Parafollicucullus monacanthus and Ishigaconus scholasticus is limited to the lower Ishigaconus scholasticus Interval Zone (middle Capitanian).

There is no certain radiolarian age of five samples (IT19120901, IT19120903, IT19120904, IT19120906 and IT19120907); however, their stratigraphic relationships (Fig. 3) likely indicate that they are the Permian in age.

\section{2 Triassic radiolarians}

Triassic radiolarians were obtained from four chert samples of Unit 3 of the Kuzu Complex in the Kiryu and Ashikaga District (Fig. 5).

Triassocampe sp. (Fig. 5.10) and Triassocampe? sp. (Fig. 5.6) were extracted from the gray chert samples, IT17021004 and IT16072004, respectively. Triassocampe Dumitrica, Kozur and Mostler and its allied genera, such as Yeharaia Nakaseko and Nishimura, occurred in the Triassic, mainly in the Anisian-middle Norian (e.g. Kozur and Mostler, 1994; Sugiyama, 1997; Tekin, 1999; O’Dogherty et al., 2009b).

Triassocampe sp. cf. T. deweveri Nakaseko and Nishimura (Figs. 5.16, 29) occurred in the gray chert sample (IT18012403) and the red chert sample (IT18110702).
The occurrence range of Triassocampe deweveri shown by Sugiyama (1997) is TR2B-TR4A, middle Anisianmiddle Ladinian. The age of these samples may be the middle Anisian-middle Ladinian. Sample IT18110702 yielded Annulotriassocampe sp. (Figs. 5.26, 5.27). The genus Annulotriassocampe Kozur occurred mainly in the Ladinian (e.g. Kozur and Mostler, 1994; O’Dogherty et al., 2009b), which supports the age assignment of the sample.

\section{3 Jurassic radiolarians]}

\section{3. 1 Chert of Unit 3 of the Kuzu Complex}

The gray chert sample (IT16072003) yielded Eucyrtidiellum gunense Cordey (Fig. 6.11), Parahsuum simplum Yao (Fig. 6.16) and Parahsuum transiens Hori and Yao (Figs. 6.13, 6.14). The occurrence ranges of Eucyrtidiellum gunense group and Parahsuum simplum are UA8-UA29 (lower Pliensbachian-middle Toarcian) and UA1-UA36 (Sinemurian-Aalenian), respectively (Carter et al., 2010). Based on the occurrence ranges, this sample is the early Pliensbachian-middle Toarcian, Early Jurassic, in age. Parahsuum transiens has intermediate characteristics between Parahsuum simplum and "Parahsuum" grande Hori and Yao (Hori and Yao, 1988). The sample yielded Parahsuum transiens but not "Parahsuum" grande, so that the sample may be older during the above-mentioned age, probably Pliensbachian.

The gray chert sample (IT19022101) yielded threesegmented closed nassellarian (Figs. 7.1, 7.2, 7.4). Three-segmented closed nassellarian is known mainly in the Family Williriedellidae Dumitrica, such as Williriedellum Dumitrica, Zhamoidellum Dumitrica, Hemicryptocapsa Tan Sin Hok, Holocryptocanium Dumitrica and Cryptamphorella Dumitrica. Threesegmented closed nassellarian is also known in Japonocapsa Kozur and Striatojaponocapsa Kozur of the Family Diacanthocapsidae O'Dogherty. These taxa occurred in the Jurassic-Cretaceous (e.g. Pessagno, 1977b; Matsuoka, 1991, 1998; Hull, 1997; Sykora et al., 1997; Yao, 1997; Hori, 1999; Kiessling, 1999; Kiessling et al., 1999; Chiari et al., 2002; O’Dogherty et al., 2006, 2009a). Consequently, the sample indicates wide range of the Jurassic-Cretaceous in age.

\section{3. 2 Siliceous mudstone of the Lower part of the Kurohone-Kiryu Complex}

The siliceous mudstone sample (IT19021701) yielded closed nassellarian (Figs. 8.1, 8.2, 8.5, 8.8). Closed nassellarian is known in the Mesozoic-Cenozoic, such as Praeprotunuma Tekin in the Triassic (Tekin, 1999), Calocyclas Ehrenberg in the Paleogene (e.g. Takemura and Ling, 1998) and Crytocapsella Haeckel in the Neogene (e.g. Sanfilippo and Riedel, 1970), in addition to three-segmented closed nassellarian that occurred in the Jurassic-Cretaceous as mentioned in subsection 4.3.1. The sample presents wide age of the Mesozoic-Cenozoic. 


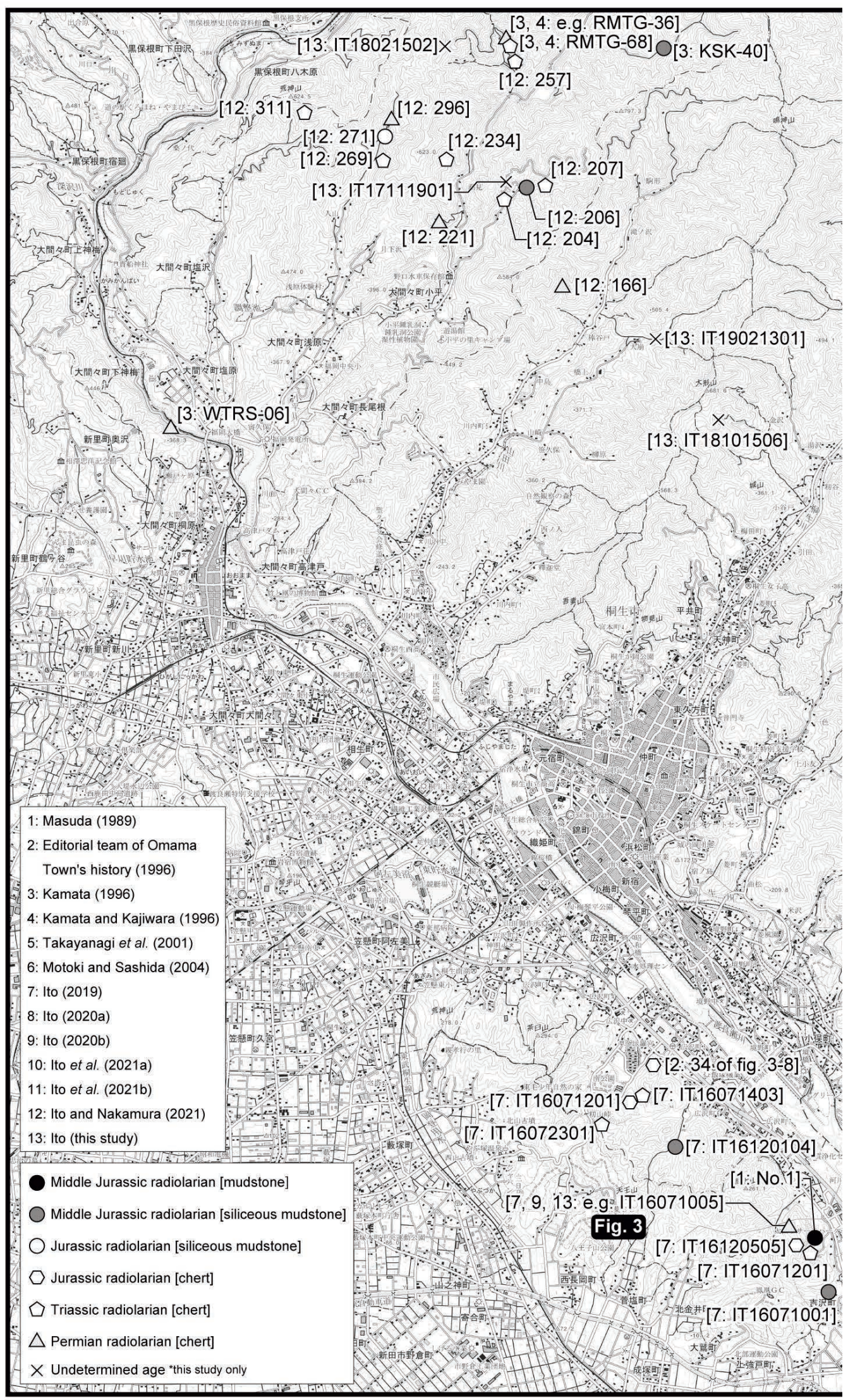




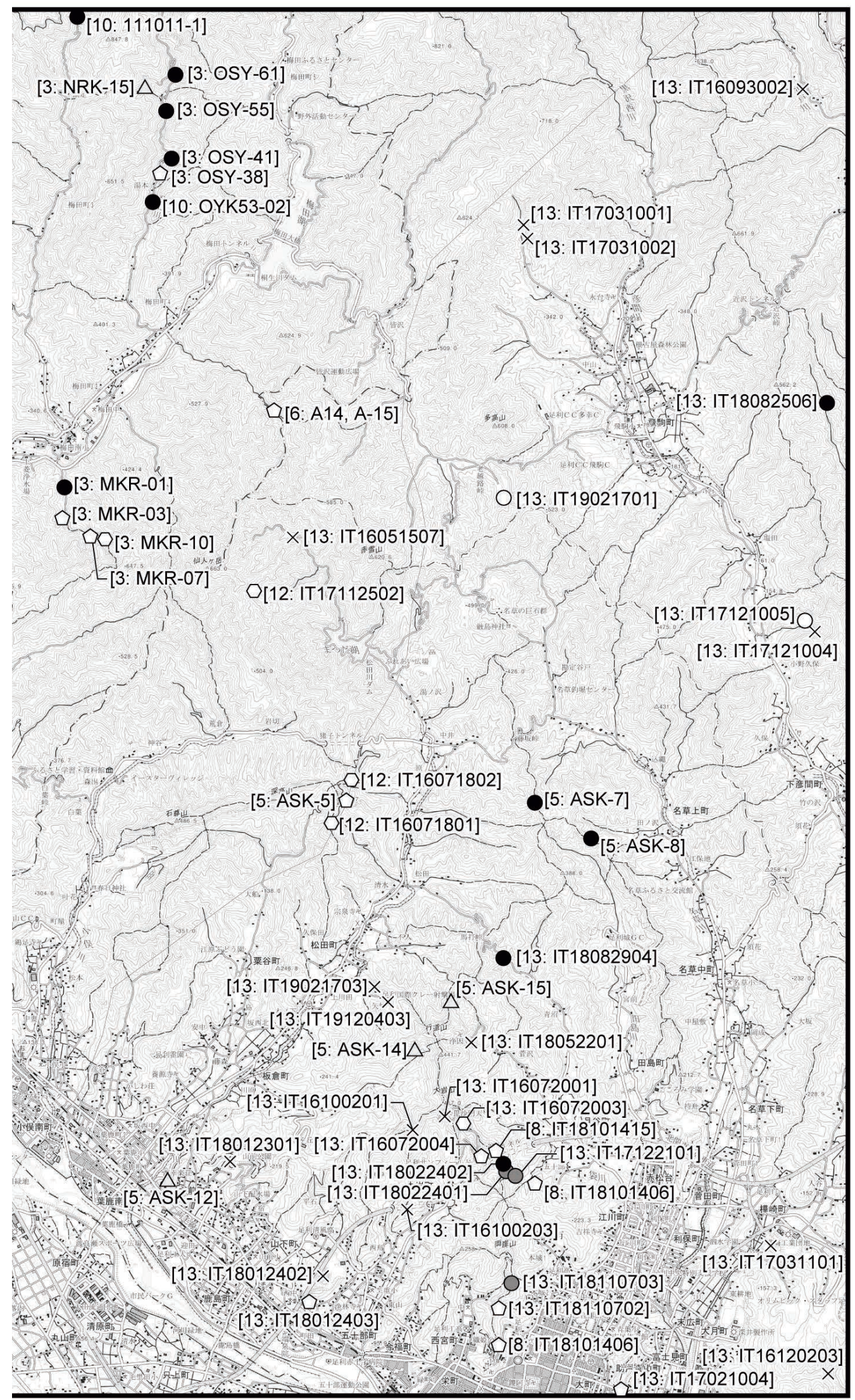

(p. 290, 291)

Fig. 2 Locality map of radiolarian occurrence sites in the present and major previous studies. Sample numbers in Fig. 3 are omitted. Base from the Geospatial Information Authority of Japan with its approval (Approval number: 419-GISMAP39354). This map uses GISMAP50000R+ "Kiryu and Ashikaga" by Hokkaido-Chizu Co. Ltd. 


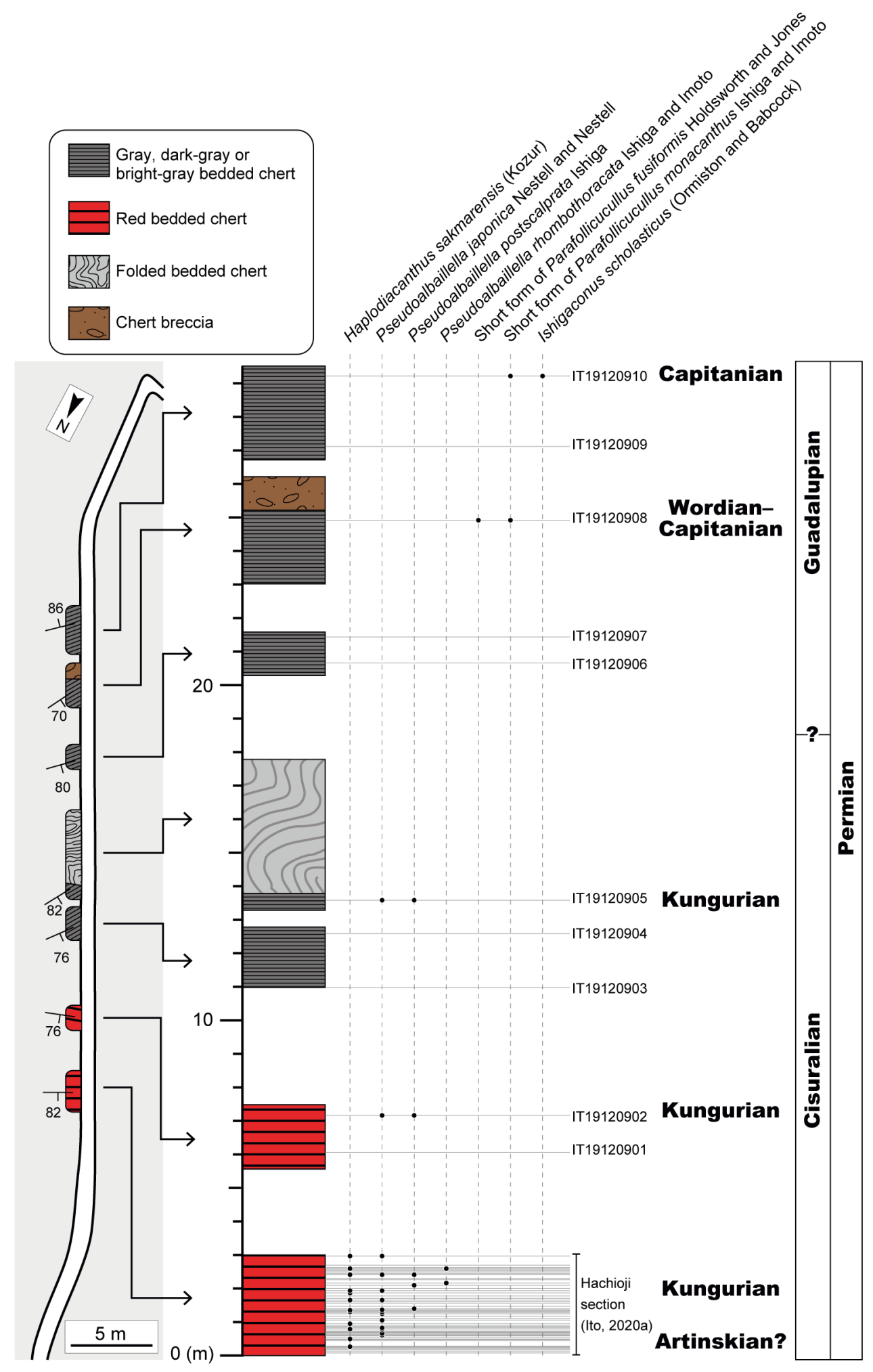

Fig. 3 Traverse map of chert sections including the Hachioji section studied by Ito (2020a) along a hiking trail at southwest of Mt. Karasawa of the Hachioji Hills. 


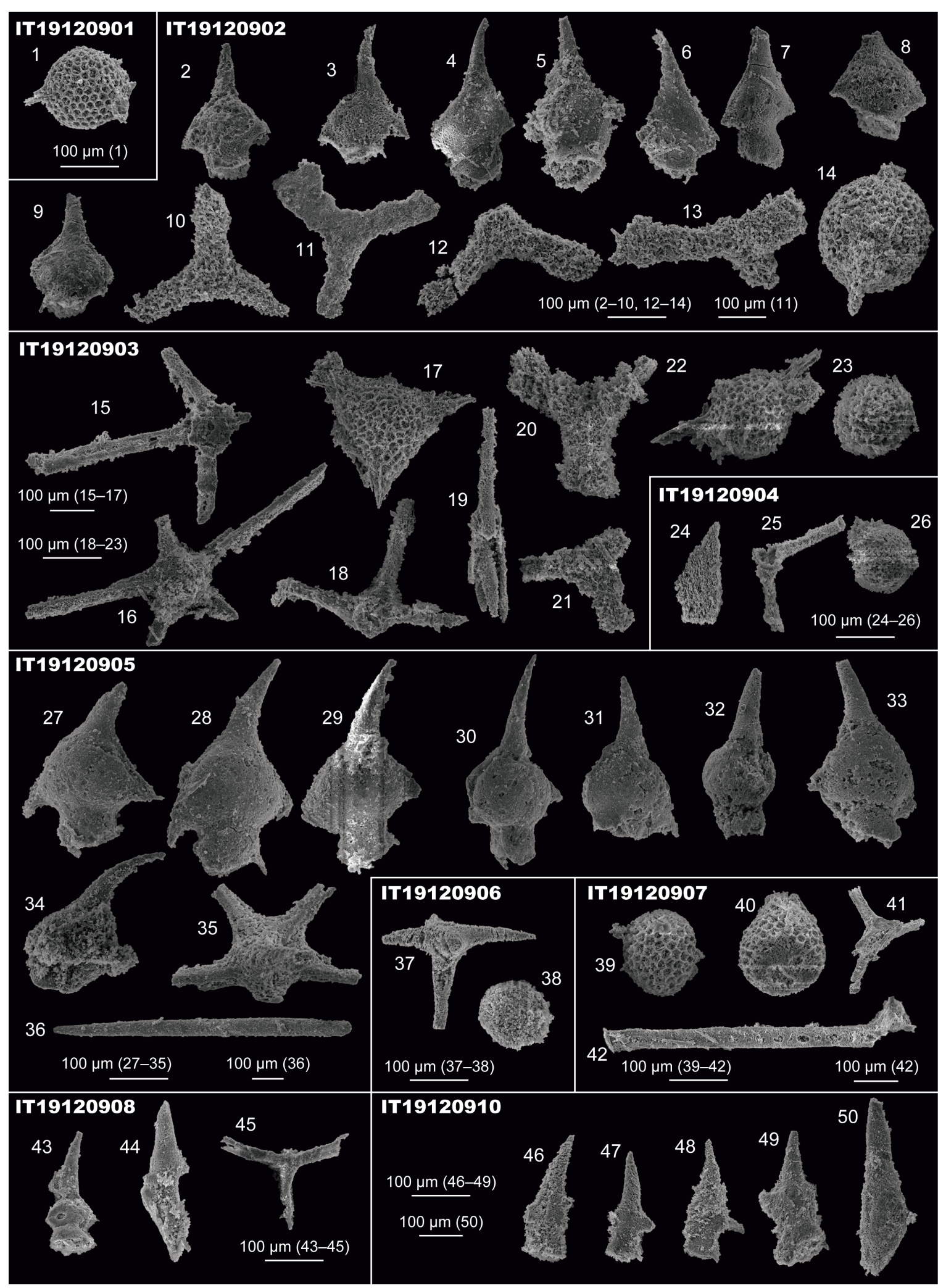

Fig. 4 Permian and possible Permian radiolarians from the chert of the Gyodosan Complex. (1, 14, 22) Stigmosphaerostylus? sp. (2-6, 8, 9, 27, 28, 31-33) Pseudoalbaillella japonica Nestell and Nestell. (7, 29, 30) Pseudoalbaillella postscalprata Ishiga. (10-13, 20, 21) Latentifistula? spp. (15) Polyfistula sp. (16, 35) Polyfistula sp. aff. P. hexalobata Nazarov and Ormiston. (17) Scharfenbergia? sp. (18, 25, 41, 45) Quadricaulis? spp. (19, 36, 37) Sponge spicule. $(23,26,38-40)$ Spherical polycystine. (24) Albaillellaria gen. et sp. indet. (34) Pseudoalbaillella? sp. (42) Arm of Latentifistularia gen. et sp. indet. (43) Short form of Parafollicucullus fusiformis Holdsworth and Jones. (44) Parafollicucullus sp. cf. P. monacanthus (Ishiga and Imoto). (46-49) Short form of Parafollicucullus monacanthus (Ishiga and Imoto). (50) Ishigaconus scholasticus (Ormiston and Babcock). 

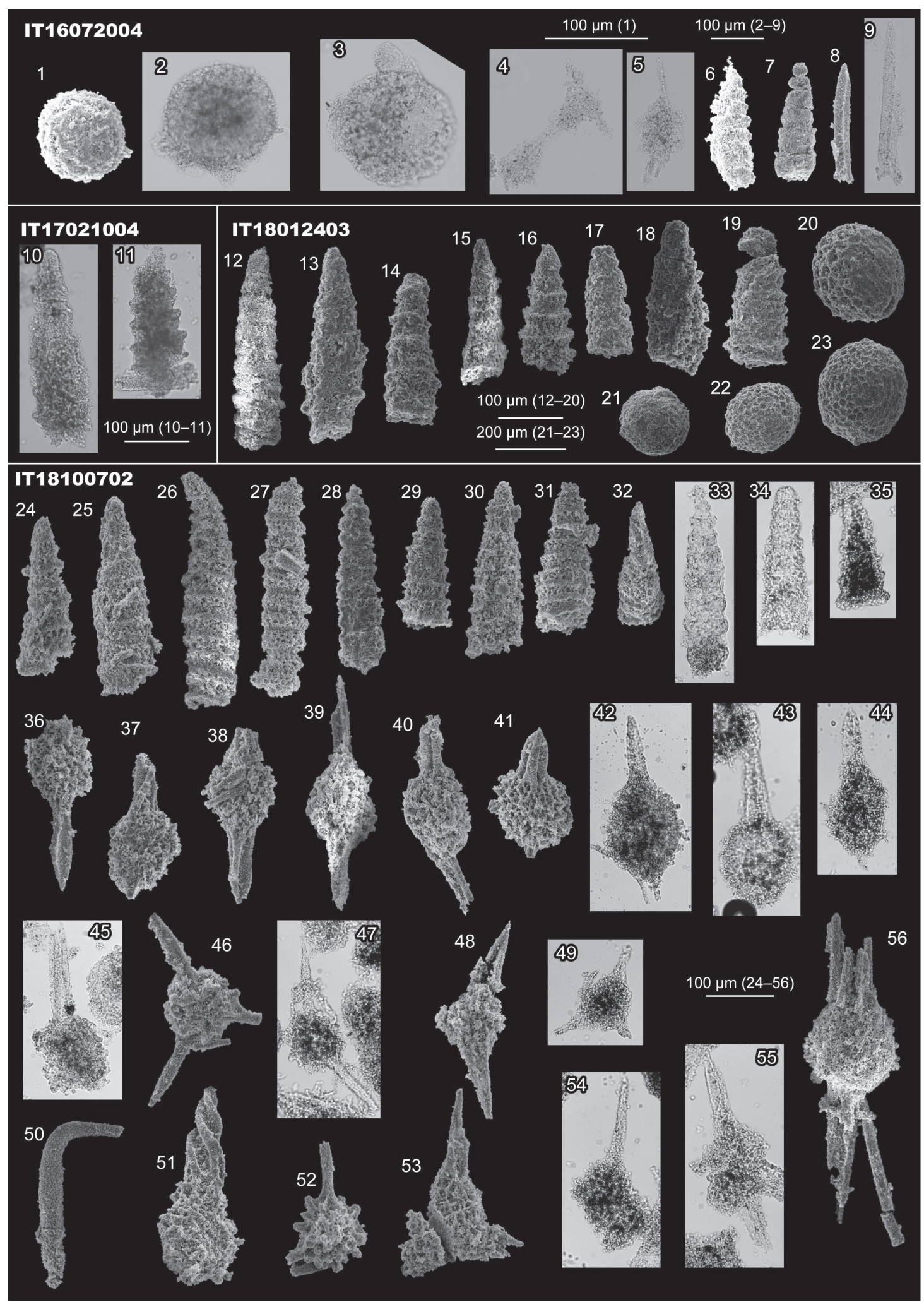

Fig. 5 Triassic radiolarians from the chert of the Kuzu Complex. (1-3, 20-23) Spherical polycystine. (4, 46, 47, 49) Three-coplanerspine-bearing spherical polycystine. (5) Pseudostylosphaera? sp. (6, 11-15, 17-19, 24, 25, 28, 31, 33, 35) Triassocampe? sp. (7) Multi-segmented nassellarian. $(8,9)$ Grooved spine. $(10,30,34)$ Triassocampe sp. $(16,29)$ Triassocampe sp. cf. T. deweveri Nakaseko and Nishimura. (26, 27) Annulotriassocampe sp. (32) Yeharaia sp. (36, 38, 41, 44) Pseudostylosphaera sp. cf. P. japonica (Nakaseko and Nishimura). (37, 39, 40, 42, 43, 45, 55, 56) Pseudostylosphaera sp. (48) Eptingium sp. cf. E. nakasekoi (Kozur and Mostler). (50) Spine A2 of Sugiyama (1997). (51) Muelleritortis? sp. (52) Xenorum? sp. (53) Capnuchosphaera? sp. (54) Spine-bearing spherical polycystine. 


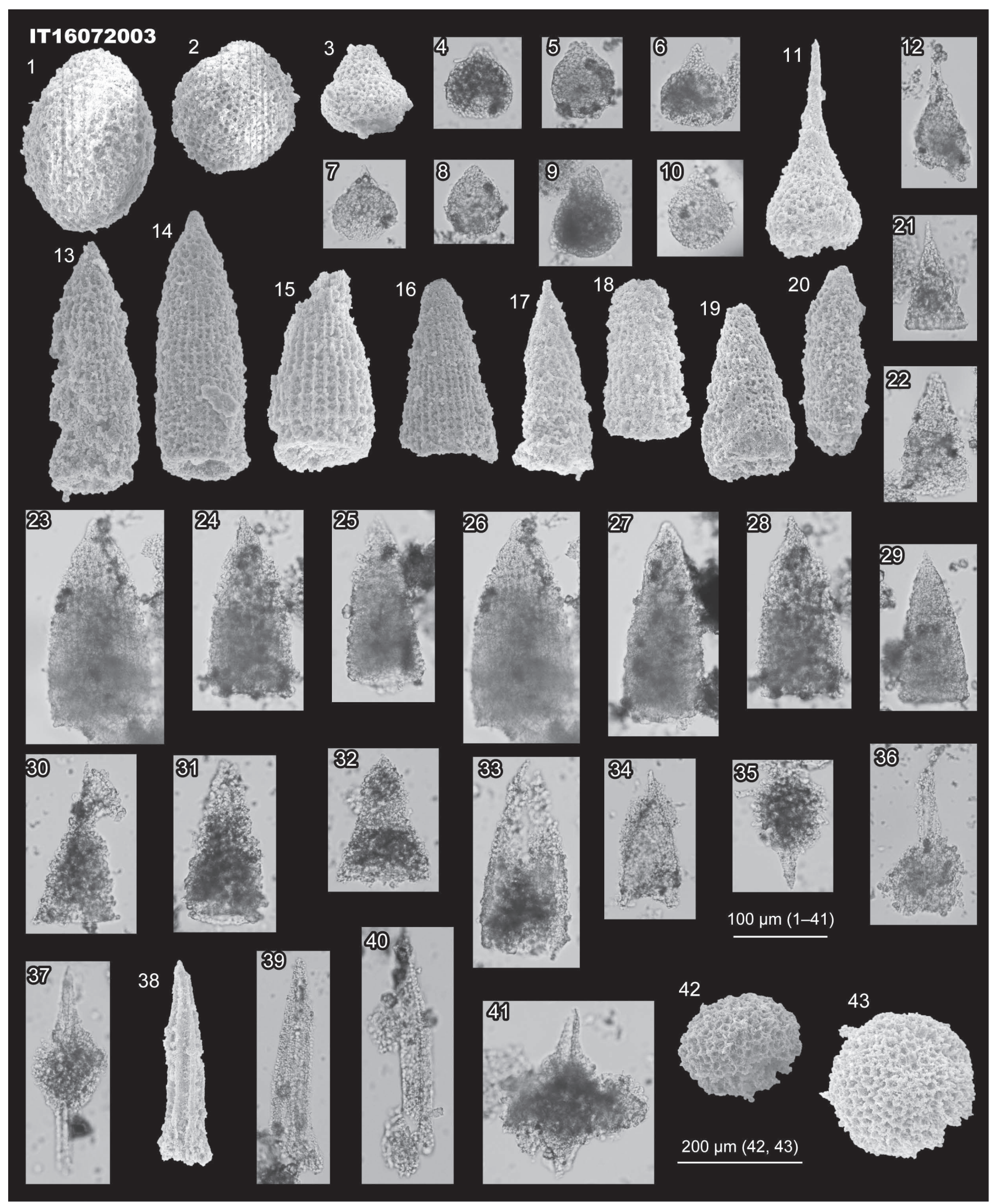

Fig. 6 Early Jurassic radiolarians from the chert of the Kuzu Complex. (1, 2) Closed nassellarian. (3, 6, 12) Eucyrtidiellum sp. (4, 5, 7-10) Three-segmented closed nassellarian. (11) Eucyrtidiellum gunense Cordey. (13, 14) Parahsuum transiens Hori and Yao. (15) Parahsuum sp. cf. P. simplum Yao. (16) Parahsuum simplum Yao. (17-21, 24, 25, 27-34) Multi-segmented nassellarian. (23, 26) Parahsuum? sp. (35-37) Pantanellium? sp. (38-40) Grooved spine. (41) Trillus? sp. (42, 43) Spherical polycystine. 


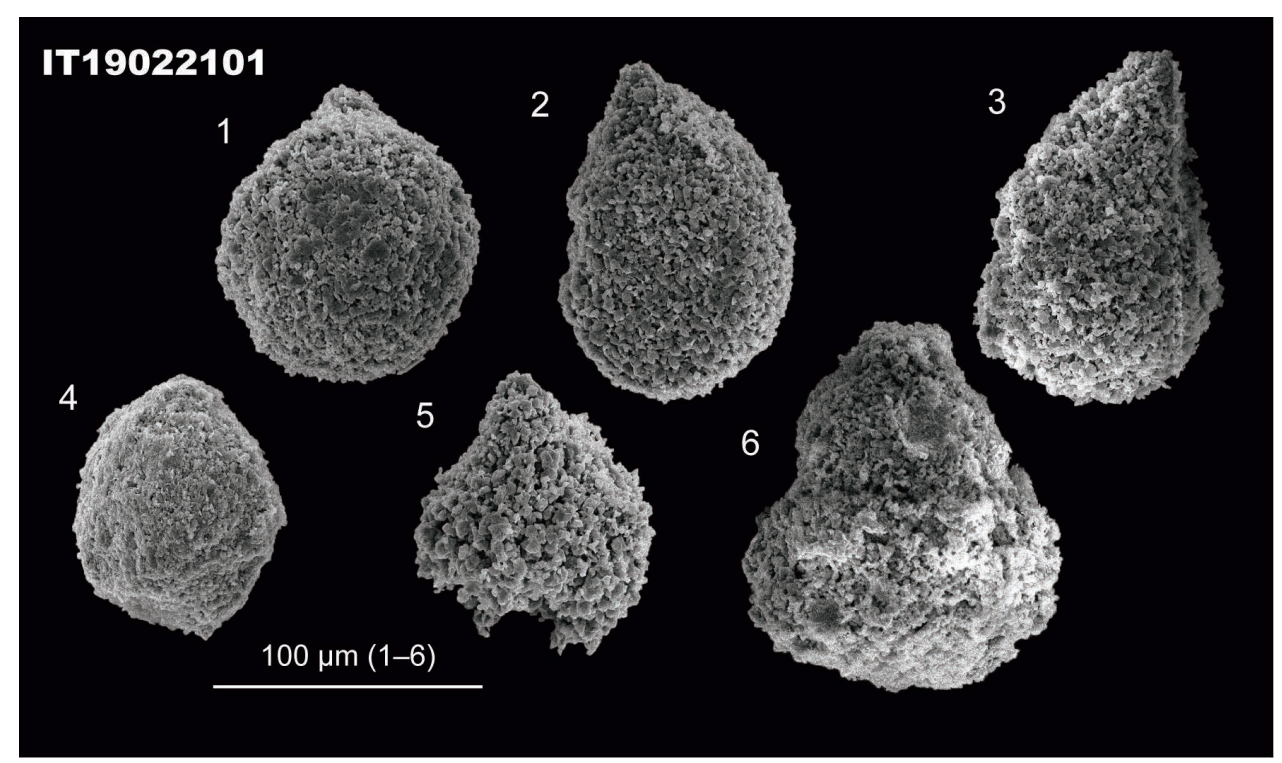

Fig. 7 Possible Jurassic radiolarians from the chert of the Kuzu Complex. (1, 2, 4) Three-segmented closed nassellarian. (3, 5, 6) Closed nassellarian.

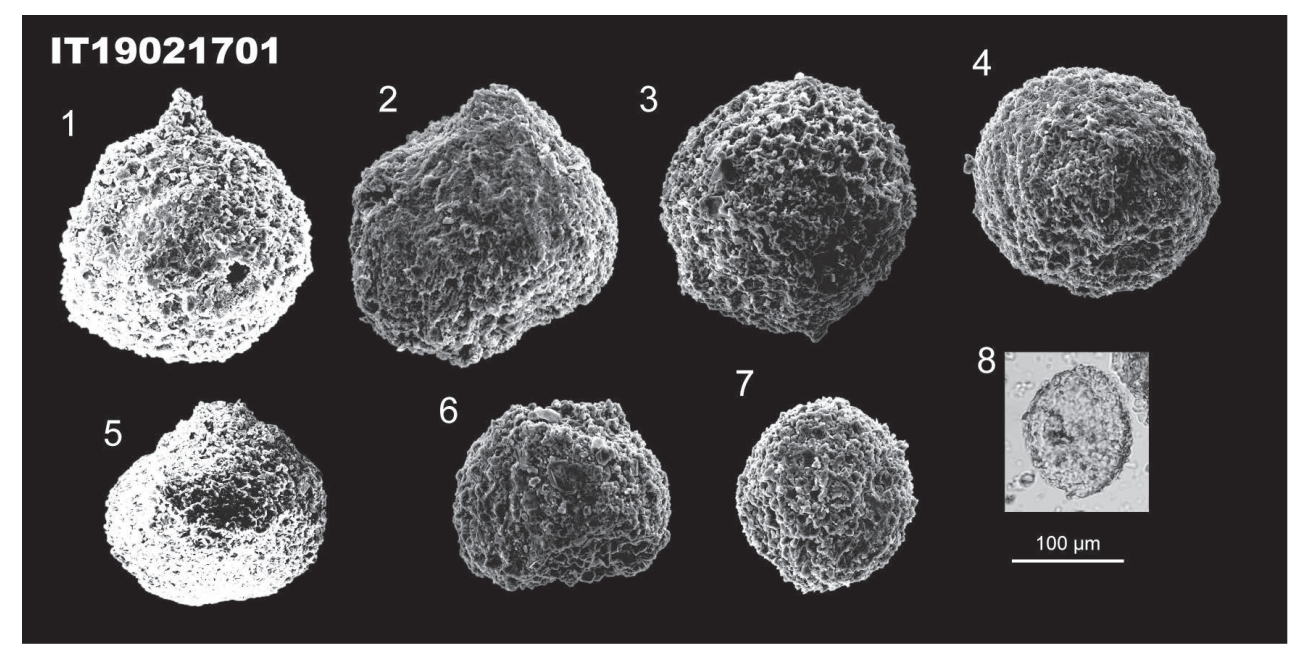

Fig. 8 Possible Jurassic radiolarians from the siliceous mudstone of the Kurohone-Kiryu Complex. $(1,2,5,8)$ Closed nassellarian. $(3,4,6,7)$ Spherical polycystine.

\section{3. 3 Siliceous mudstone of Unit 3 of the Kuzu Complex}

The bright-gray siliceous mudstone sample(IT17121005) yielded three-segmented closed nassellarian (Figs. 9.1, 9.2). As mentioned in subsection 4.3.1, three-segmented closed nassellarian occurred in the Jurassic-Cretaceous, so the age of this sample presents wide range of the Jurassic-Cretaceous.

The gray siliceous mudstone sample (IT17122101) yielded Japonocapsa sp. aff. J. fusiformis (Yao) sensu Matsuoka (1983) (Fig. 9.5). Matsuoka (1983) stated that Japonocapsa fusiformis changes gradually into Japonocapsa sp. aff. J. fusiformis near the biohorizon of the first appearance of Striatojaponocapsa conexa (Matsuoka). Striatojaponocapsa conexa is the characteristic species of JR5 (Striatojaponocapsa conexa Zone) of the upper Bathonian-Callovian, Middle Jurassic (Matsuoka and Ito, 2019). Japonocapsa sp. aff. J. fusiformis occurred also in JR6 (Kilinora spiralis Zone) (Matsuoka, 1983) corresponding to the uppermost Callovian-Oxfordian, Middle-Upper Jurassic (Matsuoka and Ito, 2019); however, the sample did not yield characteristic species of JR6. Consequently, the age of this sample is probably the late Bathonian-Callovian, Middle Jurassic.

Mizukidella? sp. (Fig. 9.31) occurred in the dark-gray siliceous mudstone sample (IT18022401). Mizukidella 
occurred in the Bajocian-Berriasian, Middle Jurassicearliest Cretaceous (O’Dogherty et al., 2017). This sample presents wide age of the Bajocian-Berriasian.

The gray siliceous mudstone sample (IT18110703) yielded Striatojaponocapsa synconexa O'Dogherty, Goričan and Dumitrica (Fig. 10.1). The occurrence range of Striatojaponocapsa synconexa is from upper JR4 (Striatojaponocapsa plicarum Zone) to lower JR5 (Striatojaponocapsa conexa Zone), Bathonian, Middle Jurassic (Matsuoka and Ito, 2019). Consequently, this sample corresponds to the Bathonian.

\section{3. 4 Mudstone of the Kuzu Complex}

The dark-gray mudstone sample(IT18022402), considered to be Unit 3 of the complex, yielded Striatojaponocapsa sp. (Fig. 11.1). Species of Striatojaponocapsa Kozur, such as Striatojaponocapsa plicarum (Yao), Striatojaponocapsa synconexa, Striatojaponocapsa riri O’Dogherty, Goričan and Dumitrica and Striatojaponocapsa conexa, occurred mainly in the Bajocian-Oxfordian (e.g. Yao, 1979; Matsuoka, 1983, 1988; Hull, 1997; Hatakeda et al., 2007; O'Dogherty et al., 2006, 2009a). Thus, the age of the sample is most probably the Bajocian-Oxfordian.

The dark-gray mudstone sample (IT18082506) yielded three-segmented closed nassellarian (Figs. 11.6, 11.7). As mentioned in subsection 4.3.1, three-segmented closed nassellarian occurred in the Jurassic-Cretaceous. Thus, this sample presents wide age of the Jurassic-Cretaceous.

\section{3. 5 Mudstone of the Gyodosan Complex}

Pelitic mixed rock (IT18082904) yielded Archaeodictyomitra sp. (Fig. 12.11). Species of Archaeodictyomitra Pessagno occurred mainly in the Jurassic-Cretaceous (e.g. Pessagno, 1977b; Pessagno and Whalen, 1982; Aita, 1987; Yang, 1993; Dumitrica-Jud, 1995; Hori, 1999; Kozai et al., 2006; O’Dogherty et al., 2006, 2009a). Matsuoka (1986) discussed lineages and occurrence ranges of several multisegmented nassellarian including Archaeodictyomitra. According to the description, this genus appeared around the Pliensbachian, middle Early Jurassic. Although the detailed age is unknown, this sample presents wide age of the middle Early Jurassic-Cretaceous.

\section{4 Undetermined-age radiolarians}

Poorly preserved radiolarians were obtained from 19 samples (Fig. 13). The ages of these samples cannot be determined.

\section{Fossil age of each lithology of the Jurassic accretionary complex of the Ashio Mountains}

Radiolarian occurrences from the Jurassic accretionary complex in the Kiryu and Ashikaga District were presented in chapter 3. Figure 14 shows the age assignment of the samples. On the basis of the radiolarian occurrences in this study and previously-reported fossil occurrences (e.g. radiolarian, conodont, fusulinid), fossil age of lithology presents for each complex in the Jurassic accretionary complex in this chapter. Figure 15 represents the relationships of the fossiliferous rocks and occurrence fossils.

\section{1 Kurohone-Kiryu Complex}

The Kurohone-Kiryu Complex is distributed mainly in the Kurohone and Kiryu areas. The Kurohone area is around Kurohone-cho of Kiryu City (former Kurohone Village) located northwest of the Watarase River. The Kiryu area (eastern part of the current Kiryu City = former Kiryu City before merger with Kurohone and Niisato villages) is mainly between the Yamada and Kiryu rivers. These areas are separated by the distributional area of the Omama Complex.

Based on lithology by the present and previous studies, the lower and upper parts of the Kurohone-Kiryu Complex is distributed in the Kiryu area whereas the lower part is solely exposed in the Kurohone area. The fossil occurrences from the areas have slightly differences. For these reasons, the fossil age is described by each area, following previous studies (e.g. Kamata, 1996; Takayanagi et al., 2001).

\section{1. 1 Lower part (Kiryu area) \\ (1) Carbonate rocks}

Igo (1985) and Koike et al. (1991) discovered Triassic conodont from limestone blocks in the Kanuma District. The limestone blocks are probably located in the distributional area of the lower part of the Kurohone-Kiryu Complex. A mixed fauna of Early-Late Triassic conodonts was obtained from the limestone blocks. In particular, Epigondolella bidentata Mosher occurred in the limestone blocks (Koike et al., 1991). The occurrence range of this species is the late Norian-early Rhaetian, Late Triassic (Rigo et al., 2018), and it is the youngest conodont species in the mixed fauna. Therefore, the youngest part of the limestone blocks was deposited near the late Norian-early Rhaetian at least.

\section{(2) Siliceous claystone}

Olenekian (Early Triassic) conodont species, such as Triassospathodus abruptus (Orchard) and Triassospathodus homeri (Bender), have been reported from the siliceous claystone (Sashida et al., 1992; Motoki and Sashida, 2004; Muto and Ito, 2021).

Hayashi (1964) reported conodonts from the "Narutaki Grindstone." Although its age was given, Hayashi (1964) mentioned that the "Narutaki Grindstone" occurs in Umeda (Kiryu City) and Hikoma (Sano City). These localities contain the distributional area of the Kurohone-Kiryu Complex and possibly the Omama Complex.

\section{(3) Chert}

Triassic conodonts and radiolarians have been discovered in chert (e.g. Hayashi, 1963; Aono, 1985; Hayashi et al., 1990; Kamata, 1996; Motoki and Sashida, 2004). 

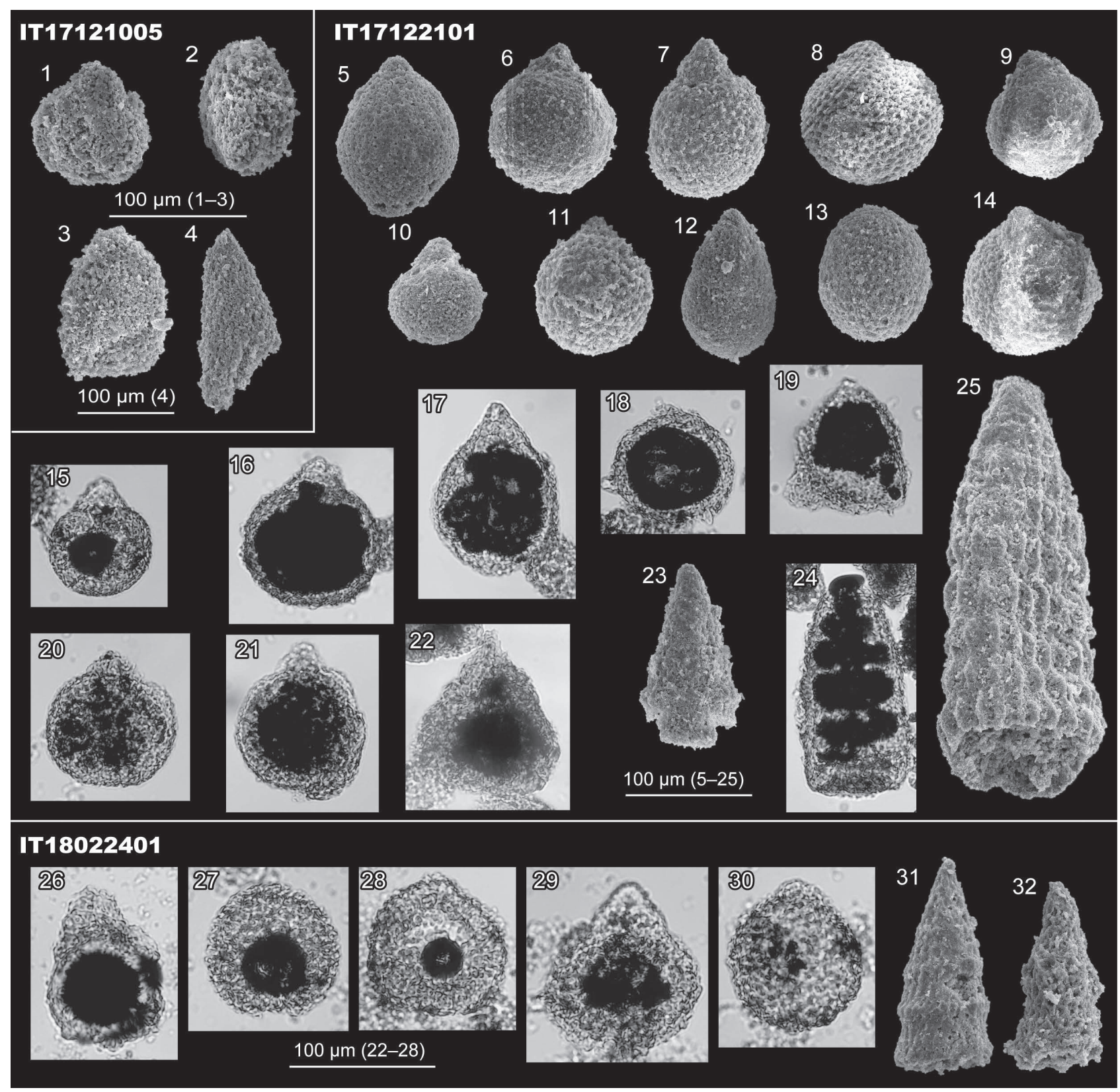

Fig. 9 Jurassic and possible Jurassic radiolarians from the siliceous mudstone of the Kuzu Complex. (1, 2, 6-11, 13-22, 27-30) Three-segmented closed nassellarian. $(3,4)$ Nassellaria gen. et sp. indet. (5) Japonocapsa sp. aff. J. fusiformis (Yao) sensu Matsuoka (1983). (12, 26) Closed nassellarian. (23, 24, 32) Multi-segmented nassellarian. (25) Hsuum maxwelli Pessagno. (31) Mizukidella? sp.

Aono (1985) reported Epigondolella primitia Mosher. Muto and Ito (2021) changed the belongingness of this species as Metapolygnathus primitius and concluded that the age is the late Carnian-early Norian (Late Triassic).

Kamata (1996) reported Yeharaia sp. and Pseudostylosphaera sp. from chert samples (e.g. MKR-18). Occurrence ranges by Sugiyama (1997) show that the Yeharaia species and Pseudostylosphaera species occurred in the uppermost Anisian-middle Ladinian and the Anisian-middle Carnian, respectively. The age of these samples is assigned as the latest Anisian-middle Ladinian.
Takayanagi et al. (2001) reported Capnodoce sp. from sample ASK-5. Species of the genus Capnodoce De Wever occurred in the upper Carnian-middle Norian, Upper Triassic (e.g. Sugiyama, 1997; O’Dogherty et al., 2009b).

Motoki and Sashida (2004) reported Pseudostylosphaera japonica, Pseudostylosphaera longispinosa Kozur and Mostler and Oertlispongus diacanthus Sugiyama. Pseudostylosphaera japonica and Oertlispongus diacanthus occurred in TR2B-TR5A (middle Anisianmiddle Carnian) and TR2A-TR2C (early-middle Anisian), respectively (Sugiyama, 1997). Consequently, 


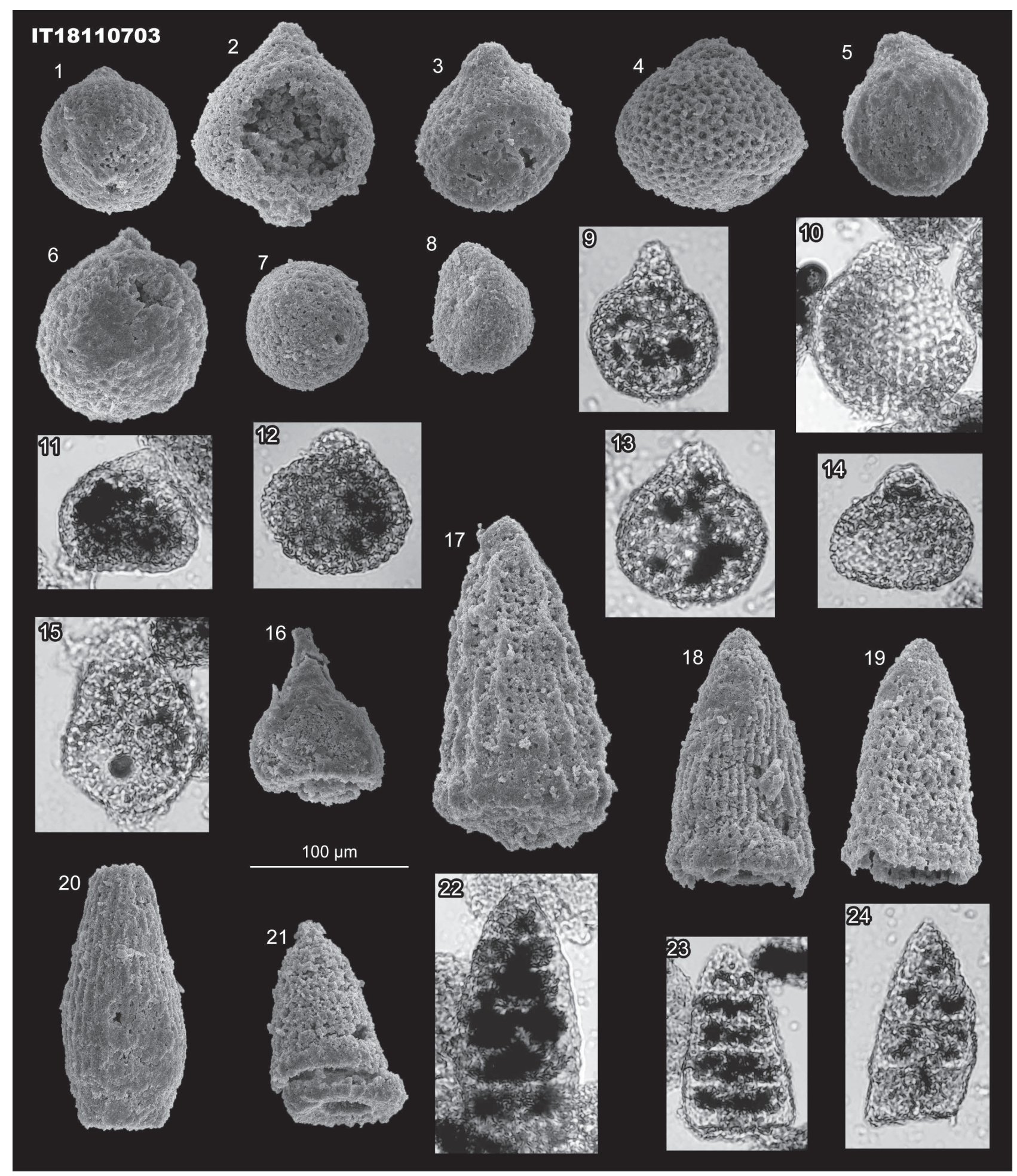

Fig. 10 Jurassic radiolarians from the siliceous mudstone of the Kuzu Complex. (1) Striatojaponocapsa synconexa O'Dogherty, Goričan and Dumitrica. (2) "Stichocapsa” sp. E sensu Baumgartner et al. (1995). (3, 5, 10) Striatojaponocapsa? sp. (4, 6-9, 11-14) Three-segmented closed nassellarian. (15) Yaocapsa? sp. (16) Eucyrtidiellum sp. cf. E. unumaense (Yao). (17) Hsuum maxwelli Pessagno. (18, 20) Archaeodictyomitra sp. (19) Takemuraella sp. cf. T. japonica (Takemura). (21-24) Multi-segmented nassellarian. 

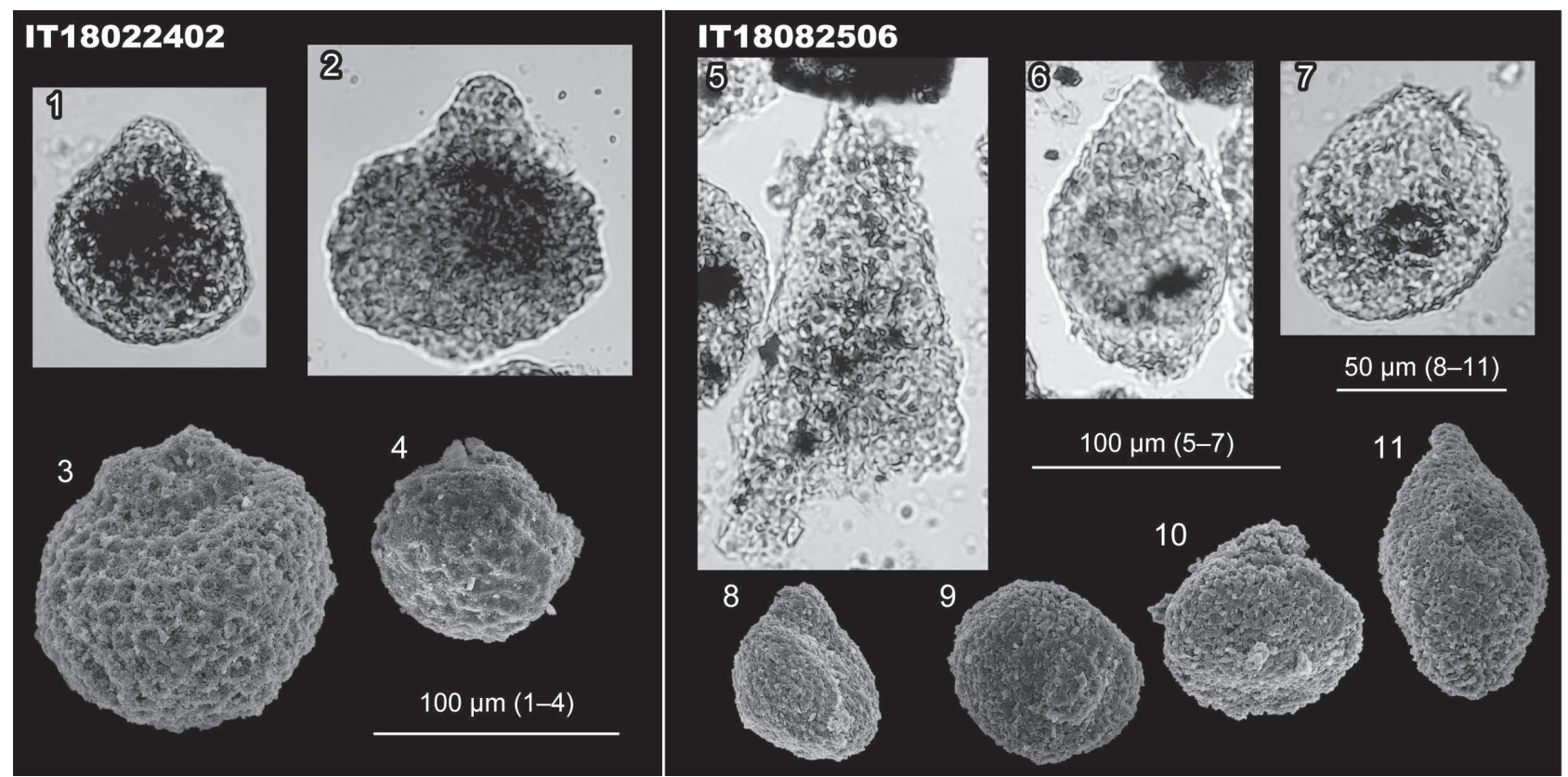

Fig. 11 Possible Jurassic radiolarians from the mudstone of the Kuzu Complex. (1) Striatojaponocapsa sp. (2) Williriedellum? marcucciae Cortese. $(3,6,7)$ Three-segmented closed nassellarian. (4, 8-11) Closed nassellarian. (5) Multi-segmented nassellarian.

the age of the sample is the middle Anisian.

\section{(4) Siliceous mudstone}

Sample IT19021701 in this study yielded closed nassellarian. Such radiolarians occurred in the MesozoicCenozoic in age, as mentioned in subsection 4.3.2.

\section{1. 2 Upper part (Kiryu area)}

\section{(1) Chert}

Triassic and Jurassic radiolarian occurrences were reported by Kamata (1996). Permian conodont, previously identified as the "Carboniferous" conodont by Hayashi et al. (1990), was reported from the possible distributional area of the upper part.

Hayashi et al. (1990) reported a specimen identified as late Carboniferous Neogondolella cf. clarki (Koike) from "Omama Town, Atago-jinjiya" (fig. 28, pl. 1, Hayashi et al., 1990). Muto and Ito (2021) re-identified the specimen as Mesogondolella sp. cf. M. gujioensis (Igo), concluding that the age is the late Artinskian-early Kungurian (Cisuralian, early Permian). The occurrence site is possibly Atagojinja Shrine in Kasagake-machi Azami, Midori City, the distributional area of the upper part.

Two samples (MKR-07 and OSY-38) reported by Kamata (1996) yielded Yeharaia sp. and Pseudostylosphaera sp. Yeharaia species and Pseudostylosphaera species occurred in the uppermost Anisian-middle Ladinian and the Anisian-middle Carnian, respectively (Sugiyama, 1997); therefore, the sample is the latest Anisian-middle Ladinian in age.

Sample MKR-03 reported by Kamata (1996) yielded Canoptum triassicum Yao and Livarella validus Yoshida.
The former is a characteristic species of the Canoptum triassicum assemblage from the middle Norian-Rhaetian (Yao, 1982); the latter occurred mainly in the Rhaetian (Yoshida, 1986). This sample is therefore the Rhaetian in age.

Sample MKR-10 reported by Kamata (1996) yielded Acanthocircus sp. This genus appeared in the Bathonian, Middle Jurassic (O’Dogherty et al., 2009a). Thus, Middle Jurassic chert may exist in the Lower part although it is not shown in Fig. 15.

\section{(2) Mudstone}

Middle Jurassic radiolarians occurred in mudstone (Kamata, 1996; Ito et al., 2021a).

Kamata (1996) reported Striatojaponocapsa plicarum (Yao) and/or Striatojaponocapsa sp. cf. S. plicarum from mudstone samples (e.g. MKR-01). Ito et al. (2021a) also reported Striatojaponocapsa plicarum from sample OYK53-02. Striatojaponocapsa plicarum occurred mainly in lower-middle JR4, Bajocian, Middle Jurassic based on the occurrence range by Matsuoka and Ito (2019). These samples are therefore the Bajocian in age.

Ito et al. (2021 a) reported Yaocapsa sp. cf. Y. mastoidea (Yao) from sample HTH12-01. The occurrence range of Yaocapsa mastoidea is limited to upper JR4, Bathonian, Middle Jurassic (Matsuoka, 1995).

\section{1. 3 Kurohone area (Lower part) \\ (1) Carbonate rocks}

Hayashi et al. (1990) reported a Triassic conodont species, Metapolygnathus sp., from limestone. Muto and Ito (2021) re-identified it as Epigondolella sp. cf. E. rigoi (Budurov). Epigondolella rigoi occurred in the uppermost 


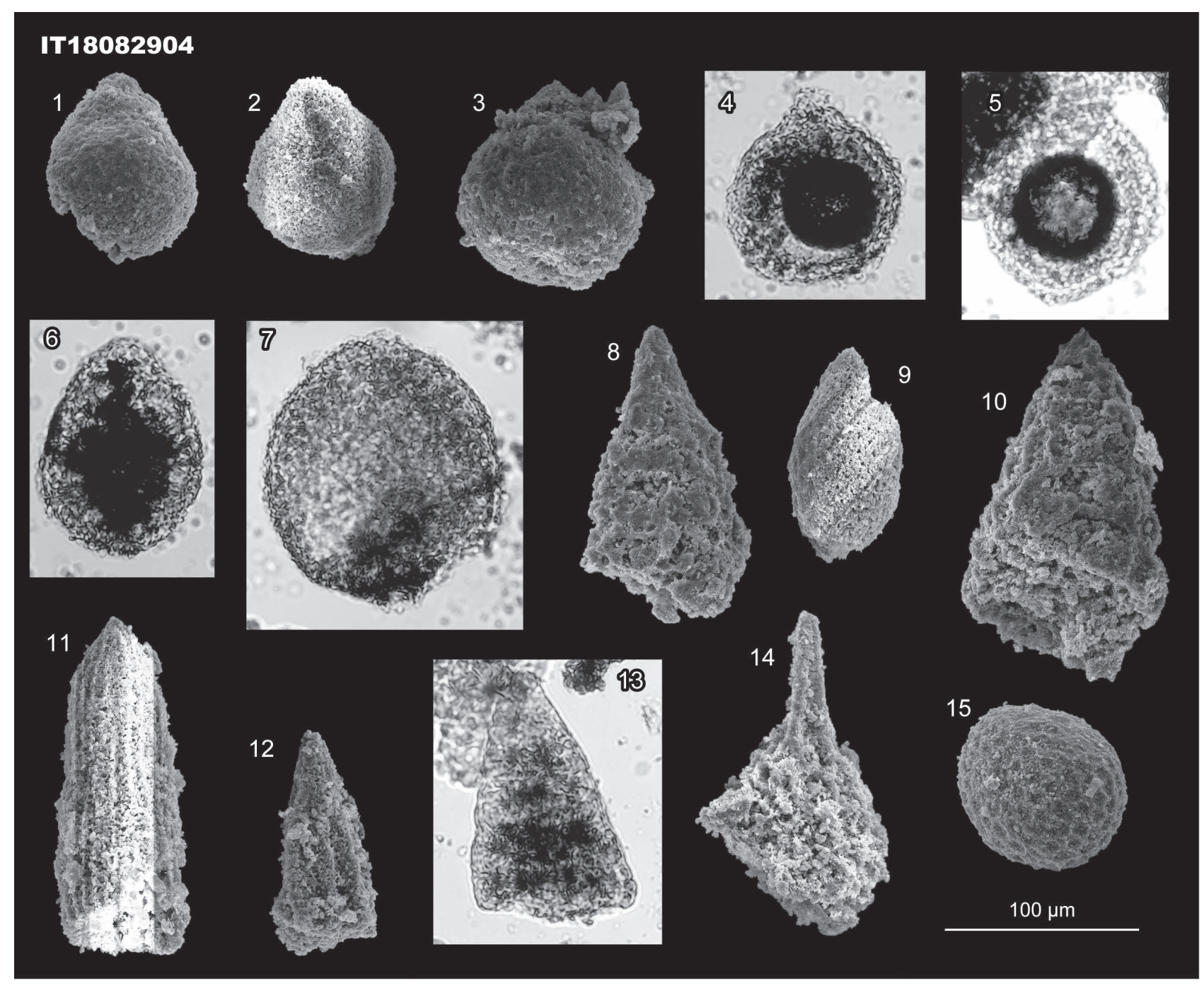

Fig. 12 Jurassic radiolarians from mudstone of the Gyodosan Complex. (1-6) Three-segmented closed nassellarian. (7, 9) Closed nassellarian. (8, 10, 12, 13) Multi-segmented nassellarian. (11) Archaeodictyomitra sp. (14) Emilvia? sp. (15) Spherical polycystine.

Carnian-lower Norian, Upper Triassic (Rigo et al., 2018).

\section{(2) Chert}

Permian and Triassic conodont and Triassic and Jurassic radiolarians occurred in chert (Hayashi et al., 1990; Kamata, 1996).

The Permian conodont species reported by Hayashi et al. (1990) is Neogondolella serrata (Clark and Ethington). Muto and Ito (2021) indicated the possibility that this specimen is Jinogondolella nankingensis (Ching). This is a characteristic species of the Roadian, Guadalupian, middle Permian (Henderson, 2018).

The Triassic conodont species reported by Hayashi et al. (1990) is Metapolygnathus sp. Muto and Ito (2021) re-identified this specimen as Epigondolella sp. cf. E. rigoi. Epigondolella rigoi occurred in the uppermost Carnian-lower Norian, Upper Triassic (Rigo et al., 2018). Several chert samples (e.g. OGR-81) reported by
Kamata (1996) yielded Triassocampe deweveri. This species occurred in TR2C-TR4A, middle Anisian-middle Ladinian, Middle Triassic (Sugiyama, 1997).

Two chert samples (TZW-104 and OGR-74) yielded Parahsuum simplum (Kamata, 1996). This is a characteristic species of JR1 (Parahsuum simplum Zone) of the upper Sinemurian-lower Pliensbachian, Lower Jurassic (Matsuoka and Ito, 2019). The samples are probably the late Sinemurian-early Pliensbachian in age.

\section{(3) Siliceous mudstone}

Striatojaponocapsa sp. cf. S. plicarum occurred in two siliceous mudstone samples (e.g. TZW-105 of Kamata, 1996). Striatojaponocapsa plicarum occurred mainly in lower-middle JR4, Bajocian, Middle Jurassic (Matsuoka and Ito, 2019). Striatojaponocapsa conexa occurred in the siliceous mudstone (TZW-111 and OGR-69 of Kamata, 1996). It is a characteristic species of JR5 of the upper 


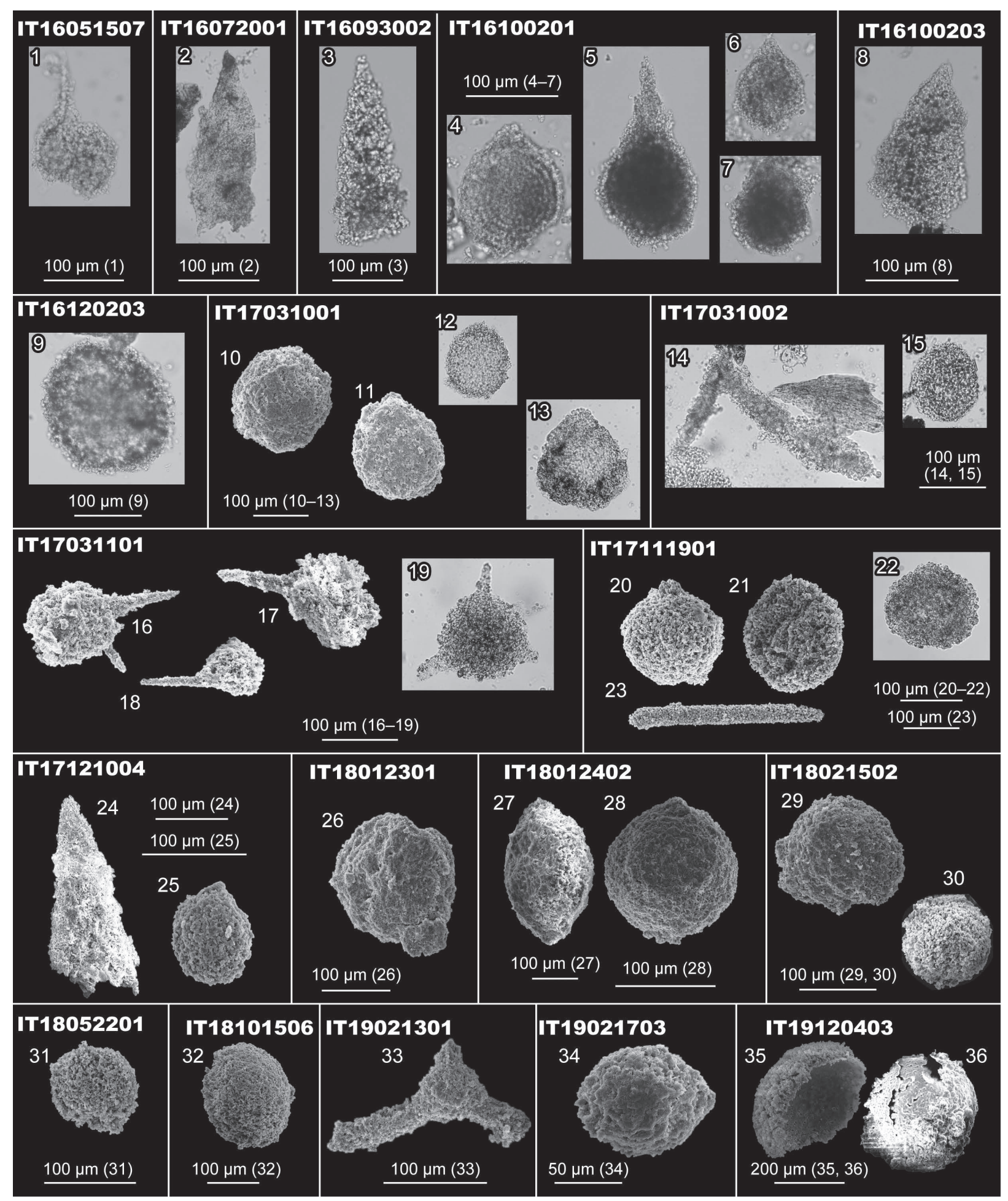

Fig. 13 Radiolarians (undetermined age) from the Jurassic accretionary complex. (1, 4-7, 9-13, 15, 20-22, 25-32, 34-36) Spherical polycystine. $(2,3,8,24)$ Multi-segmented nassellarian. $(19,33)$ Three-coplaner-spine-bearing spherical polycystine. (14, 16-18) Spine-bearing spherical polycystine. IT16051507: Chert of the Kurohone-Kiryu Complex. IT16072001: Siliceous mudstone of the Gyodosan Complex. IT16093002: Chert of the Kurohone-Kiryu Complex. IT16100201: Chert of the Gyodosan Complex. IT16100203: Chert of the Kuzu Complex. IT16120203: Chert of the Kuzu Complex. IT17031001: Chert of the Kurohone-Kiryu Complex. IT17031002: Chert of the Kurohone-Kiryu Complex. IT17031101: Chert of the Kuzu Complex. IT17111901: Chert of the Omama Complex. IT17121004: Mudstone of the Kuzu Complex. IT18012301: Chert of the Gyodosan Complex. IT18012402: Chert of the Kuzu Complex. IT18021502: Chert of the Omama Complex. IT18052201: Chert of the Gyodosan Complex. IT18101506: Chert of the Omama Complex. IT19021301: Chert of the Omama Complex. IT19021703: Mudstone of the Kuzu Complex. IT19120403: Mudstone of the Gyodosan Complex. 


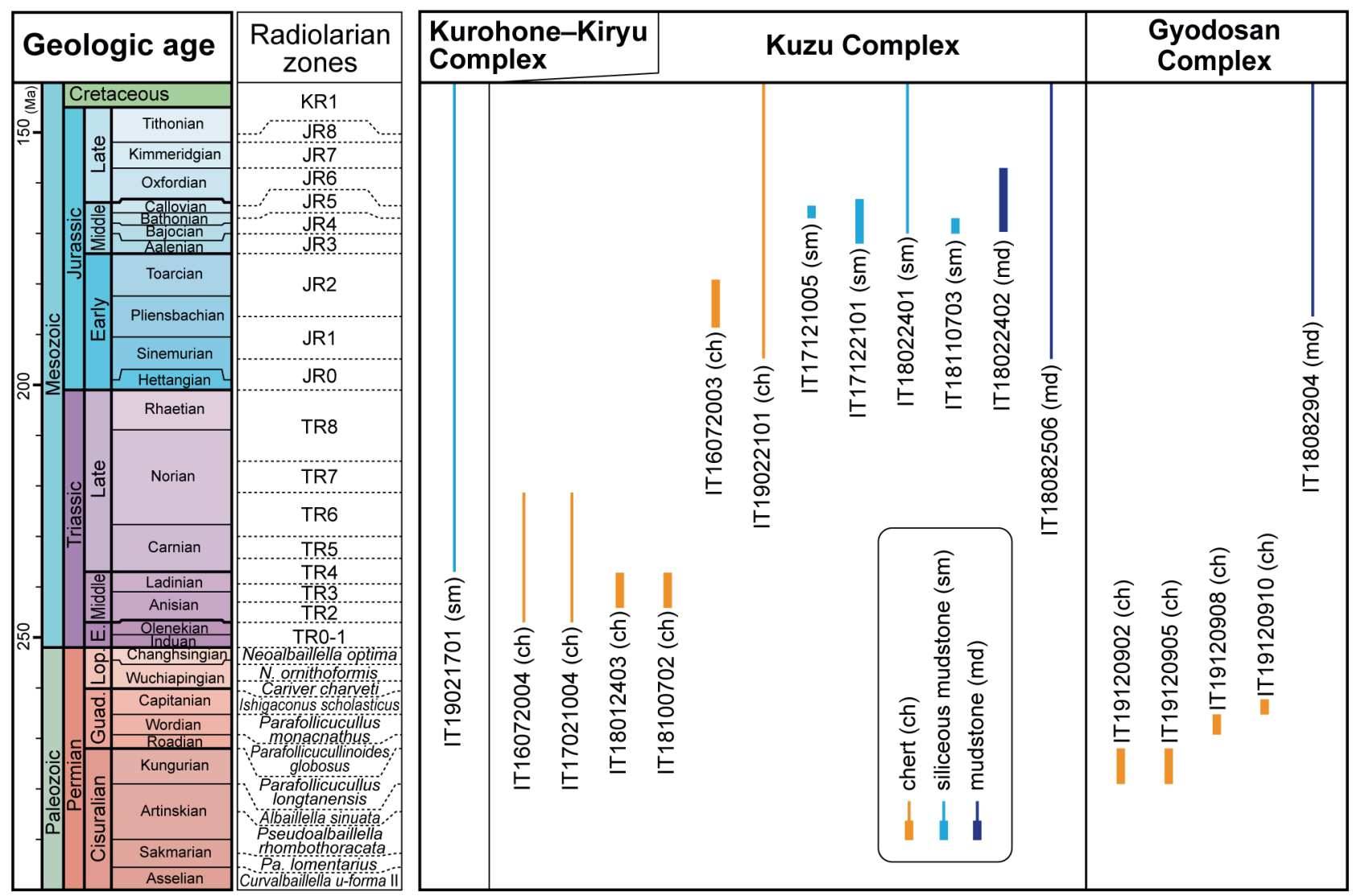

Fig. 14 Age assignment of the samples reported in this study. Geologic age follows Ogg et al. (2016). Radiolarian zones are based on Ishiga (1986, 1990), Sugiyama (1997), Kuwahara et al. (1998) and Matsuoka and Ito (2019). The names of Permian radiolarian zones are changed according to taxonomic reevaluation by Xiao et al. (2020, 2021). E.: Early; Lop.: Lopingian; Guad.: Guadalupian; N.: Neoalbaillella; Pa.: Parafollicucullinoides. Samples reliable in age are presented as thick bars, whereas those unreliable as thinner bars.

Bathonian-middle Callovian (Matsuoka and Ito, 2019).

\section{(4) Mudstone}

Striatojaponocapsa plicarum occurred in mudstone (e.g. OGR-17 of Kamata, 1996). Striatojaponocapsa plicarum occurred mainly in the lower-middle JR4, Bajocian, Middle Jurassic (Matsuoka and Ito, 2019).

\section{2 Omama Complex}

\section{2. 1 Lower part}

\section{(1) Carbonate rocks}

Carbonate rocks of the Omama Complex have yielded several types of fossils, such as fusulinids (Kawata and Ozawa, 1955; Hayashi and Hasegawa, 1981; Editorial team of Omama Town's history, 1996; Ito, 2021; Ito et al., 2021b), brachiopods (Hayashi and Hasegawa, 1981; Editorial team of Omama Town's history, 1996; Tazawa and Takakuwa, 2009; Tazawa et al., 2012), corals (Editorial team of Omama Town's history, 1996; Igo et al., 2000), trilobites (Kobayashi and Hamada, 1984; Koizumi et al., 1988; Editorial team of Omama Town's history, 1996) and chondrichthyes (Yabe, 1903; Reif and Goto, 1979; Takakuwa and Okabe, 2011; Takakuwa, 2021).
Occurrences of pre-Permian conodonts from the carbonate rocks have been reported by previous studies. Hayashi et al. (1990) and Editorial team of Omama Town's history (1996) claimed the presence of the "Devonian" and "Carboniferous" carbonate rocks, respectively, based on conodont occurrences such as Neogondolella sp. cf. N. clarki. However, Muto and Ito (2021) re-identified the conodont fossils and re-considered their ages as the Triassic. No certain evidence indicates the presence of the pre-Permian conodont from the carbonate rocks to date, thus the pre-Permian carbonate rocks are not shown in Fig. 15.

\section{(2) Siliceous claystone}

Kamata and Kajiwara (1996) investigated a continuous section composed of siliceous claystone and alternations of chert and siliceous claystone. They found conodonts (Neogondolella bulgarica (Budurov and Stefanov)) and radiolarians (Triassocampe myterocorys Sugiyama and Oertlispongus diacanthus). Neogondolella bulgarica is currently assigned as Paragondolella bulgarica, which is indicative of being the middle Anisian (Nicora, 1977; Chen et al., 2016). 

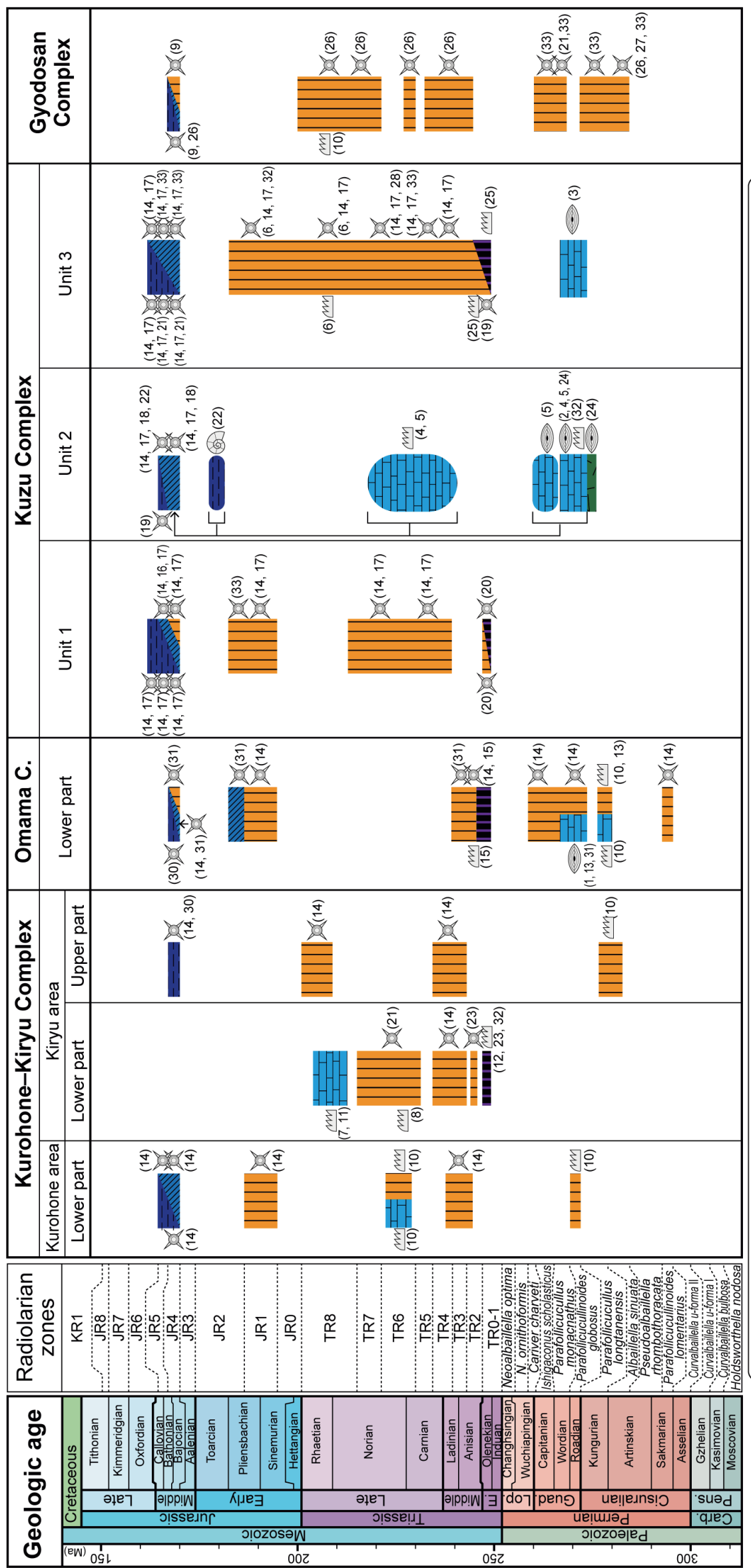
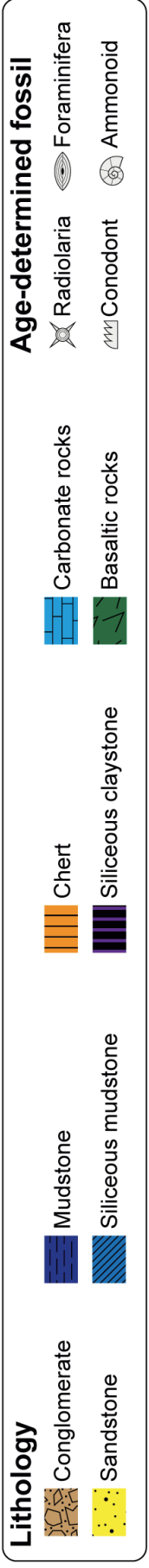

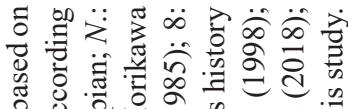

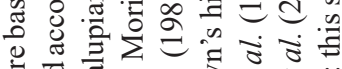

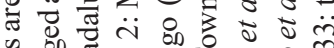

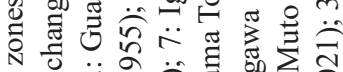
N

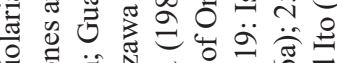

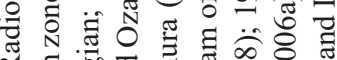

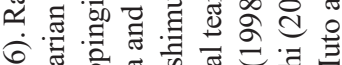
응

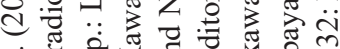

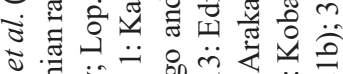

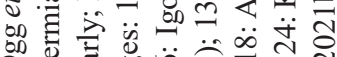

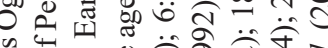
n 응 嵌 의.

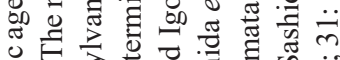

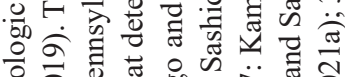

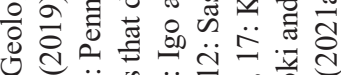

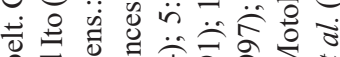
8 च छ

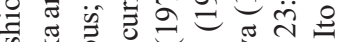

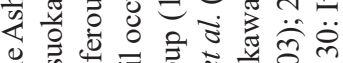

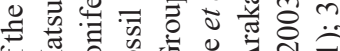

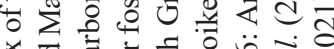
× 言命诸

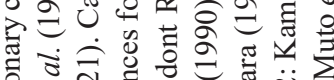

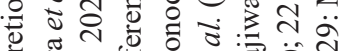

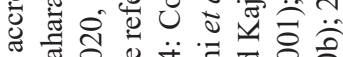

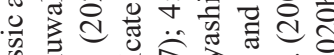
क्ष

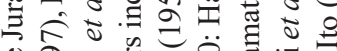

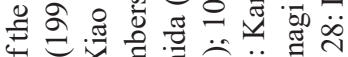

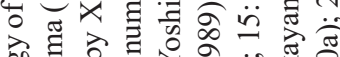
응.

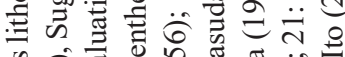

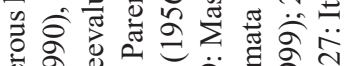

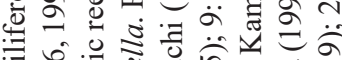

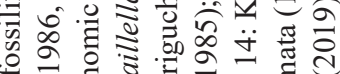

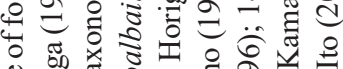

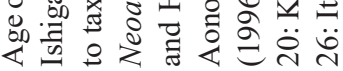




\section{(3) Chert}

Permian, Triassic and Jurassic radiolarians occurred in chert (Kamata, 1996; Ito et al., 2021b).

Parafollicucullinoides lomentarius (Ishiga) was obtained from sample NRK-15 of Kamata (1996). This species is a characteristic species of Parafollicucullinoides lomentarius Zone of the Sakmarian of Ishiga (1990). Parafollicucullus fusiformis Holdsworth and Jones occurred in sample WTRS-06 of Kamata (1996). This species occurred abundantly in the Guadalupian (e.g. Ishiga, 1990; Zhang et al., 2014). Follicucullus japonica Ishiga, currently identified as Follicucullus porrectus Rudenko, was obtained from several samples (e.g. RMTG-36 of Kamata, 1996). Follicucullus porrectus was the characteristic species of the Follicucullus porrectus Interval Zone (lower Capitanian) of Zhang et al. (2014).

Pseudostylosphaera japonica and Oertlispongus diacanthus Sugiyama were obtained from sample RMTG-68 of Kamata (1996). The former and latter species occurred in TR2B-TR5A (middle Anisian-middle Carnian) and TR2A-TR2C (early-middle Anisian), respectively (Sugiyama, 1997). The co-occurrence of these genera is limited to the middle Anisian (Sugiyama, 1997).

Two samples (\#204 and \#269) yielded Triassocampe sp. cf. T. coronata Bragin (Ito et al., 2021b). Triassocampe coronata occurred in the Anisian, Middle Triassic (Sugiyama, 1997).

Sample KSK-28 reported by Kamata (1996) yielded Parahsuum simplum. This is a characteristic species of the JR1 of the upper Sinemurian-lower Pliensbachian (Matsuoka and Ito, 2019); thus, this sample is probably the late Sinemurian-early Pliensbachian.

Protunuma sp. cf. P. fusiformis Ichikawa and Yao occurred in sample \#271 reported by Ito et al. (2021b). Protunuma fusiformis occurred with Striatojaponocapsa plicarum, the characteristic species of JR4 of the Bajocian-lower Bathonian in previous studies (e.g. Matsuoka, 1985). Based on the occurrence, this sample is probably the Bajocian-Bathonian in age.

Hayashi et al. (1990) reported "early Carboniferous" conodonts from the Asabara area, the distributional area of the Omama Complex. Based on re-identification by Muto and Ito (2021), many of the illustrated specimens by Hayashi et al. (1990) were identified as Late Triassic species and some specimens are similar to Permian ones, while early Carboniferous species were not confirmed. Therefore, no certain evidence indicates the presence of the pre-Permian conodont from the chert to date.

Hayashi et al. (1990) reported Neogondolella sp. cf. $N$. clarki from the chert (fig. 34, pl. 1, Hayashi et al., 1990). Muto and Ito (2021) re-identified them as Mesogondolella gujioensis (Igo). The occurrence range of this species is the late Artinskian-early Kungurian (Henderson, 2018).

\section{(4) Siliceous mudstone}

Middle Jurassic radiolarians occurred in siliceous mudstone (Kamata, 1996; Ito et al., 2021b).
Sample KSK-40 reported by Kamata (1996) yielded Striatojaponocapsa plicarum. Striatojaponocapsa plicarum occurred mainly in the lower-middle JR4, Bajocian, Middle Jurassic (Matsuoka and Ito, 2019).

Sample \#206 reported by Ito et al. (2021b) yielded Archaeodictyomitra sp. cf. A. exiguum Blome. Archaeodictyomitra exiguum was described on the basis of the specimens from the Callovian in the North America (Blome, 1984). This species also cooccurred with Striatojaponocapsa plicarum (Hattori, 1987), which occurred mainly in lower-middle JR4, Bajocian (Matsuoka and Ito, 2019). Consequently, the occurrence range of Archaeodictyomitra exiguum include the Bajocian-Callovian at least.

Sample \#154 reported by Ito et al. (2021b) yielded Eucyrtidiellum sp. aff. E. omanojaponicum Dumitrica, Goričan and Hori. Eucyrtidiellum omanojaponicum (= Eucyrtidiellum? sp. C of Hori, 1990, 1997) occurred in the upper JR 1 corresponding approximately to the Pliensbachian (Hori, 1990, 1997).

\section{(5) Mudstone}

Ito et al. (2021a) reported two mudstone samples that yielded Middle Jurassic radiolarians based on the occurrence ranges of Matsuoka (1995) and Matsuoka and Ito (2019). Sample 111013-4 corresponds to lower-middle JR4, Bajocian; sample 111011-1 corresponds to upper JR4, lower Bathonian.

\section{2. 2. Upper part}

Due to the lacking detail information, the upper part is not presented in Fig. 15. However, the Carboniferous carbonate rocks may exist in the upper part.

Fujimoto (1960) reported corals (Amygdalophyllum naosoidea Minato, Lithostrotion pseudomartini Yabe and Hayasaka and Chaetetes sp.) from "limestone lenses" of the Kawamo Formation in the Takatsudo Gorge in Midori City. Pelitic mixed rock around the Takatsudo Gorge is a typical representation of the upper part of the Omama Complex, so the "limestone lenses" are probably the blocks within the pelitic mixed rock. The age of the corals is assigned as the Visean (Mississippian, early Carboniferous) based on description by Minato (1951, 1955). Although the photographs were not presented, the upper part might include Carboniferous carbonate rocks as blocks within the pelitic mixed rock.

\section{3 Kuzu Complex}

\subsection{Unit 1}

\section{(1) Siliceous claystone}

Early Triassic radiolarians and conodonts occurred in the siliceous claystone and intercalated chert within the siliceous claystone (Kamata, 1995, 1999). Kamata (1999) reported Spathian conodonts, such as Triassospathodus curtatus Orchard (Originally described as Neospathodus triangularis (Bender)), from sample TNK-R-09.

\section{(2) Chert}


Triassic conodonts and Triassic and Jurassic radiolarians occurred in chert (e.g. Hayashi, 1968a, b; Koike et al., 1970, 1971; Kamata, 1995, 1996, 1997a, 1999).

Kamata (1996, 1997a) reported abundant Middle Triassic-Early Jurassic radiolarians from the chert. Yao et al. (1982) recognized four radiolarian assemblages from Middle Triassic-Early Jurassic, namely Triassocampe deweveri, Triassocampe nova, Canoptum triassicum and Parahsuum simplum assemblages. Characteristic species of these assemblages were obtained from the chert samples excluding Canoptum triassicum Yao.

Striatojaponocapsa plicarum was obtained from sample KS-01 of (Kamata, 1996, 1997a). This is a characteristic species of JR4, Bajocian-lower Bathonian (Matsuoka and Ito, 2019).

Kamata (1997b) described a float block of radiolarianbearing chert breccia in the distributional area of Unit 1 . He extracted Permian and Triassic radiolarians from the chert breccia. The chert breccia is not presented in Fig. 15.

\section{(3) Siliceous mudstone}

Middle Jurassic radiolarians occurred in siliceous mudstone (Kamata, 1996, 1997a; Arakawa, 1997).

Striatojaponocapsa plicarum were reported from siliceous mudstone samples (e.g. IZW-31 of Kamata, 1996, 1997a; SAY-02 of Arakawa, 1997). This is a characteristic species of JR4, Bajocian-lower Bathonian (Matsuoka and Ito, 2019). Striatojaponocapsa conexa, characteristic species of JR5 of the upper Bathonianmiddle Callovian (Matsuoka and Ito, 2019), occurred in the siliceous mudstone samples (SPS-04 of Kamata, 1996, 1997a; SAY-01 of Arakawa, 1997). Consequently, the age of the mudstone ranges from the Bajocian to middle Callovian.

\section{(4) Mudstone}

Middle-Late Jurassic radiolarians occurred in mudstone (Kamata, 1996, 1997a).

The mudstone samples (e.g. AOKI-09 of Kamata, 1996, 1997a) yielded Striatojaponocapsa plicarum and Striatojaponocapsa conexa, which are characteristic species of JR4 and JR5, respectively. Kilinora spiralis (Matsuoka) was discovered from the mudstone (e.g. IZW30 of Kamata, 1996, 1997a). This is a characteristic species of JR6 of the upper Callovian-Oxfordian (Matsuoka and Ito, 2019). Consequently, the age of the mudstone ranges from the Bajocian to Oxfordian.

\section{3. 2 Unit 2}

Unit 2 comprises basaltic rocks, carbonate rocks, siliceous mudstone and mudstone, in ascending order. The siliceous mudstone intercalates limestone conglomerate layers.

\section{(1) Basaltic rocks}

Middle Permian foraminifers were obtained from limestone clasts included within basaltic rocks
(Kobayashi, 2006a, b). According to Kobayashi (2006a, b), foraminifers from the limestone clasts correspond to the Parafusulina nakamigawai Zone to the lowermost Parafusulina yabei Zone. The Parafusulina yabei Zone corresponds to the middle Kungurian, lower Permian, based on the global fusuline biostratigraphy by Zhang and Wang (2018). This study tentatively regards the basaltic rocks as the middle Kungurian.

\section{(2) Carbonate rocks}

Carbonate rocks yielded abundant fossils, such as brachiopods (Hayasaka 1926, 1944; Tazawa et al., 2016), foraminifers (Yabe, 1899; Hujimoto, 1938; Yoshida, 1956, 1957; Morikawa and Horiguchi, 1956; Morikawa and Takaoka, 1961; Fujimoto, 1961; Igo, 1964; Hatori, 1965; Saito and Kato, 1971; Conodont Research Group, 1972, 1974; Igo et al., 1976; Igo and Igo, 1977; Kobayashi, 1979, 2006a, b), conodonts (Hayashi, 1971; Conodont Research Group, 1972, 1974; Koike et al., 1974; Igo et al., 1976; Muto et al., 2021), trilobites (Fujimoto, 1961; Koizumi et al., 1979), coral (Yamagiwa and Tsuda, 1980) and chondrichthyes (Goto, 1975, 1984, 1994; Reif and Goto, 1979).

The carbonate rocks correspond to the middle Parafusulina yabei to Parafusulina tochigiensis zones, according to fusuline biostratigraphy constructed by Kobayashi (2006a, b). The Parafusuina yabei Zone corresponds to the middle Kungurian (Zhang and Wang, 2018); middle Parafusulina tochigiensis Zone corresponds to the Wordian (Kobayashi, 2006a). Muto et al. (2021) reported conodont fossils, Mesogondolella idahoensis (Youngquist, Hawley and Miller) and Sweetognathus hanzhonensis (Wang), from samples (e.g. 2014-215) belonging to the middle Parafusulina yabei Zone. The conodont species indicate the late Kungurian in age. Thus, the carbonate rocks are the late Kungurian-Wordian, early-middle Permian in age.

\section{(3) Siliceous mudstone}

Middle Jurassic radiolarians occurred in siliceous mudstone (Kamata, 1996, 1997a; Arakawa, 1998; Kamata and Mizobe, 2001; Kamata et al., 2003).

Striatojaponocapsa plicarum occurred in siliceous mudstone samples (e.g. YZK-14 of Kamata, 1996, 1997a). This is a characteristic species of JR4, Bajocian-lower Bathonian, Middle Jurassic (Matsuoka and Ito, 2019).

Striatojaponocapsa conexa were obtained from sample YZK-13 of Kamata (1996, 1997a). This is a characteristic species of JR5, upper Bathonian-Callovian, Middle Jurassic (Matsuoka and Ito, 2019).

Arakawa (1998) extracted radiolarian assemblages from manganese dioxide nodules (KUS01, KUS02, KUS03) in the siliceous mudstone. The former two samples yielded Striatojaponocapsa plicarum, and the latter one sample yielded Striatojaponocapsa conexa.

The limestone conglomerate is intercalated in the siliceous mudstone. Middle Permian foraminifers 
and Middle-Upper Triassic conodonts were obtained from limestone gravels within the conglomerate (e.g. Morikawa and Horiguchi, 1956; Conodont Research Group, 1974; Igo and Igo, 1977). In addition, Kamata et al. (2003) discovered ammonite, Cleviceras sp. cf. $C$. chrysanthemum (Yokoyama), from a mudstone pebble within the conglomerate. The age of the ammonite is assigned as the early-middle Toarcian, Early Jurassic (Kamata et al., 2003). Kamata and Mizobe (2001) and Kamata et al. (2003) also determined the radiolarians of siliceous mudstone beds that intercalates the ammonitebearing conglomerate and extracted radiolarians of JR4 (Bajocian-lower Bathonian, Middle Jurassic) of Matsuoka and Ito (2019).

Based on these occurrences, Fig. 15 shows that middle Permian and Middle-Upper Triassic limestone gravels and Lower Jurassic mudstone gravels are included in the Middle Jurassic siliceous mudstone.

\section{(4) Mudstone}

Isogawa et al. (1998) described radiolarian assemblages including Striatojaponocapsa conexa from mudstone samples (YZB-02, 03, 05). This is a characteristic species of JR5 of the upper Bathonian-Callovian (Matsuoka and Ito, 2019).

\section{3. 3 Unit 3 \\ (1) Carbonate rocks}

Yoshida (1957) and Fujimoto (1961) described Permian fusulinids (e.g. Parafusulina sp.) from limestone in the distributional area of Unit 3. The limestone was considered as the component of Unit 3 (e.g. Yoshida, 1957; Kamata, 1997a). Meanwhile, several researchers mentioned another opinion that it is the component of Unit 2 (e.g. Fujimoto, 1961; Yanagimoto, 1973).

\section{(2) Siliceous claystone}

Muto et al. (2018) investigated a continuous section consisting of siliceous claystone and chert, namely the Ogama section, and extracted conodonts and radiolarians. According to their work, almost of the siliceous claystone beds correspond to the Olenekian-lower Anisian.

\section{(3) Chert}

Several studies reported Triassic conodonts and Triassic and Jurassic radiolarians from chert (Kamata, 1996, 1997a; Isogawa et al., 1998; Ootaka et al., 1998; Takayanagi et al., 2001; Suzuki et al., 2002; Ito, 2020b).

Isogawa et al. (1998) reported Early Triassic radiolarians, such as Parentactinia nakatsugawaensis. Muto et al. (2018) discovered middle Anisian conodont, Paragondolella bulgarica Budurov and Stefanov.

Igo and Nishimura (1984) discovered conodont and radiolarian occurrences from Upper Triassic-Lower Jurassic continuous sections. Kamata (1996, 1997a) reported abundant Middle Triassic-Early Jurassic radiolarians. All characteristic species of the four assemblages proposed by Yao et al. (1982), namely Triassocampe deweveri, Triassocampe nova, Canoptum triassicum and Parahsuum simplum assemblages, were obtained. Sample IT16072003 is the early Pliensbachianmiddle Toarcian of the Early Jurassic as mentioned in subsection 4.3.1. Due to the abundant fossil occurrences of Triassic-Early Jurassic, the chert of this unit is represented as a continuous sequence in Fig. 15.

\section{(4) Siliceous mudstone}

Striatojaponocapsa plicarum, Striatojaponocapsa conexa and Kilinora spiralis were discovered in siliceous mudstone samples (e.g. KOM-05 of Kamata, 1996, 1997a). These are characteristic species of JR4 (Bajocianlower Bathonian), JR5 (upper Bathonian-Callovian) and JR6 (uppermost Callovian-Oxfordian), respectively (Matsuoka and Ito, 2019). As mentioned in subsection 4.3.3, the ages of samples IT17122101 and 18110703 are late Bathonian-Callovian and Bathonian, respectively. Thus, the age of the siliceous mudstone ranges from the Bajocian to Oxfordian.

\section{(5) Mudstone}

Striatojaponocapsa plicarum and Striatojaponocapsa conexa occurred in mudstone samples (e.g. KD-05 of Kamata, 1996, 1997a; ASK-8 of Takayanagi et al., 2001). Kilinora spiralis was obtained from sample KOM-04 of Kamata (1996, 1997a). The age of the mudstone ranges from the Bajocian to Oxfordian.

\section{4 Gyodosan Complex \\ (1) Chert}

Permian, Triassic and Jurassic radiolarians with a few conodonts have been reported from chert (Masuda, 1989; Hayashi et al., 1990; Takayanagi et al., 2001; Sashida, 2008; Ito, 2019, 2020a).

Ito (2019) reported early Permian radiolarians from the red chert samples (IT16071005 and IT16071006). Thereafter, Ito (2020a) investigated the radiolarian fauna from the Hachioji section including the sample horizons of Ito (2019). Based on the occurrences of Haplodiacanthus sakmarensis (Kozur), Pseudoalbaillella japonica, Pseudoalbaillella postscalprata and Pseudoalbaillella rhombothoracata Ishiga and Imoto, Ito (2020a) concluded that the lower to middle parts of the Hachioji section partially correspond to the lower Kungurian and may include the uppermost Artinskian. In addition, the Wordian and Capitanian chert near the Hachioji section was identified in this study (Fig. 3) as mentioned in section 4.1 .

Ito (2019) reported Triassic radiolarians from the following samples. Sample IT16071201 yielded spines A2, B5, D1 and D2 of Sugiyama (1997). The cooccurrence range of these spines is restricted to TR6A, uppermost Carnian-lowermost Norian (Sugiyama, 1997). Sample IT16071403 yielded spines C and D1 of Sugiyama (1997). Co-occurrence range of these spines 
is limited in the TR5A, Carnian (Sugiyama, 1997). Sample IT16071405 yielded Mesosaturnalis octospinus Sugiyama. This species occurred in TR7-TR8A, middle Norian (Sugiyama, 1997). Sample IT16071402 yielded Praehexasaturnalis sp. cf. P. tenuispinosus (Kozur and Mostler). The occurrence range of the Praehexasaturnalis tenuispinosus group is TR7-JR0A, middle Norian-lower Hettanginian, Upper Triassic-lowermost Jurassic (Sugiyama, 1997). Sample IT16112604 yielded Tritortis kretaensis (Kozur and Krahl). This species occurred in TR4A-TR5A, upper Ladinian-lower Carnian, MiddleUpper Triassic (Sugiyama, 1997).

Hayashi et al. (1990) reported Triassic conodont, Misikella sp., from the "Ota City, Maruyama" (figs. 7, 8, pl. 1, Hayashi et al., 1990). This is possibly located in the distributional area of the Gyodosan Complex. According to age re-consideration by Muto and Ito (2021), the age is the latest Norian-Rhaetian, Late Triassic.

Some possible Jurassic radiolarians were obtained from chert. For example, Takayanagi et al. (2001) reported Pantanellium? sp. from two samples (ASK-13 and ASK-15); Ito (2019) reported Parahsuum sp. from sample IT16071206. Certain Jurassic radiolarians were reported by Masuda (1989): a chert sample (No. 9) yielded Eucyrtidiellum unumaense (Yao) and Unuma echinatus Ichikawa and Yao. The former species occurred mainly in JR4-JR5 of the Bajocian-lower Callovian (Matsuoka, 1995); the latter species occurred in JR3-JR4, AalenianBathonian (Matsuoka and Yao (1986). Based on the co-occurrence, the chert sample is JR4, Bajocian-lower Bathonian in age.

\section{(2) Siliceous mudstone}

Ito (2019) discovered Striatojaponocapsa synconexa from sample IT167071001. This species occurred in upper JR4-lower JR5, Bathonian (Matsuoka and Ito, 2019).

\section{(3) Mudstone}

Masuda (1989) reported a radiolarians assemblage indicating JR4 (Bajocian-lower Bathonian) from the chert. He noted that a similar radiolarian assemblage was obtained from the manganese nodule (sample No. 1) in the mudstone, although photographs were not shown. The mudstone of this complex is the Bajocian-lower Bathonian in age.

\section{Reconstruction of ocean plate stratigraphy}

In this article, the author reported Permian, Triassic and Jurassic radiolarian occurrences from the Kiryu and Ashikaga District and determined their ages (Fig. 14). In addition, previous fossil occurrences from the Jurassic accretionary complex including neighbor districts (e.g. Kuzu District) were summarized (Fig. 15).

This article provides basic data on age of the Jurassic accretionary complex in the Ashio Mountains and essential information for reconstruction of ocean plate stratigraphy (OPS) of each complex of the Jurassic accretionary complex. The OPS of an accretionary complex presents lithologic change reflecting history of an ocean plate from birth at a mid ocean ridge to subduction at a trench via an abyssal plain. The OPS of the Jurassic accretionary complexes in Japan is generally composed of basaltic rocks, carbonate rocks, chert, siliceous mudstone, mudstone and sandstone, in ascending order (e.g. Isozaki et al., 1990; Matsuda and Isozaki, 1991; Nakae, 2000; Wakita and Metcalfe, 2005; Wakita, 2015).

The OPS of each complex of the Jurassic accretionary complex in the Ashio Mountains is reconstructed here (Fig. 16). The fossil occurrences were described by each distributed area and stratigraphic part for the KurohoneKiryu and Omama complexes in chapter 5 . In this chapter, the author reconstructs the OPS of the complexes using the merged data from each area and part.

The Kurohone-Kiryu Complex comprises basaltic rocks (possibly early Permian), chert (early-middle Permian, Middle-Late Triassic and Early Jurassic), siliceous claystone (Early Triassic), carbonate rocks (Late Triassic), siliceous mudstone (Middle Jurassic), mudstone (Middle Jurassic) and sandstone (possibly Middle Jurassic).

The Omama Complex comprises basaltic rocks (possibly early Permian), chert (early-middle Permian, Middle Triassic and Early Jurassic), carbonate rocks (early-middle Permian), siliceous claystone (possibly Early Triassic), siliceous mudstone (Early-Middle Jurassic), mudstone (Middle Jurassic) and sandstone (possibly Middle Jurassic).

In the Kuzu Complex, Unit 1 comprises siliceous claystone (Early Triassic), chert (Early-Late Triassic and Early-Middle Jurassic), siliceous mudstone (Middle Jurassic), mudstone (Middle-Late Jurassic) and sandstone (possibly Late Jurassic). Unit 2 comprises basaltic rocks (early Permian), carbonate rocks (early-middle Permian), siliceous mudstone (Middle Jurassic) and mudstone (Middle Jurassic). The siliceous mudstone of Unit 2 interbeds conglomerate layers containing gravels of carbonate rocks (early-middle Permian and Middle-Late Triassic) and mudstone (Early Jurassic). Unit 3 comprises basaltic rocks (possibly middle Permian), carbonate rocks (middle Permian), siliceous claystone (Early Triassic), chert (Early-Late Triassic and Early Jurassic), siliceous mudstone (Middle-Late Jurassic), mudstone (MiddleLate Jurassic) and sandstone (possibly Late Jurassic).

The Gyodosan Complex is composed of chert (earlymiddle Permian, Middle-Late Triassic and Middle Jurassic), siliceous mudstone (Middle Jurassic), mudstone (Middle Jurassic) and sandstone (possibly Middle Jurassic).

\section{Paleontological note}

The taxonomic classification in this chapter mainly employs the scheme of De Wever et al. (2001), O'Dogherty et al. (2009a, b) and Noble et al. (2017). 


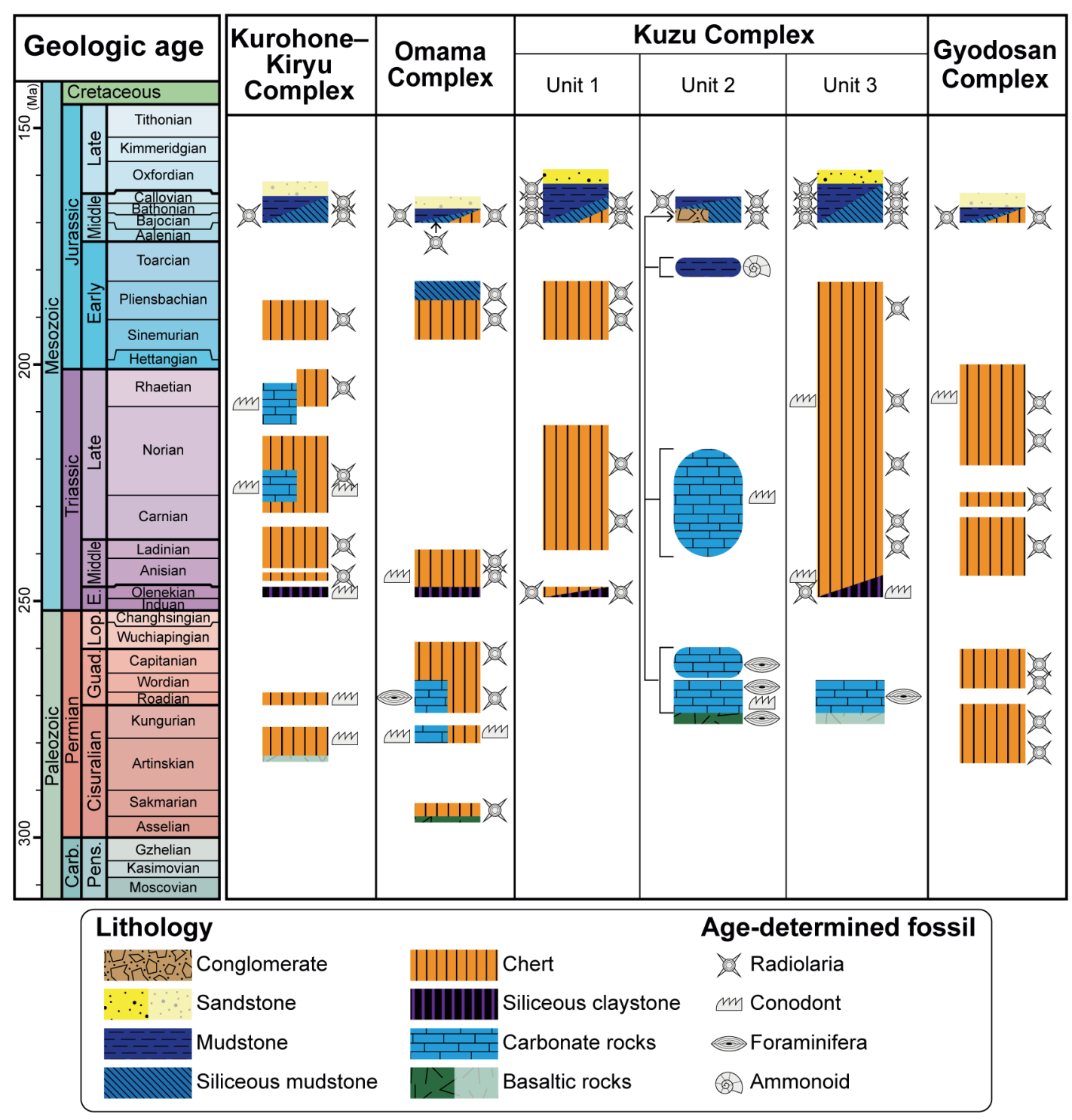

Fig. 16 Reconstructed ocean plate stratigraphy of the Jurassic accretionary complex of the Ashio belt. Geologic age follows Ogg et al. (2016). Deep-colored lithology with fossil illustration: its age is relatively-precisely determined by fossil. Deep-colored lithology without fossil illustration: although its component rock has never yielded age-determined fossil, its age can be speculated based on stratigraphical relationships with overlying and underlying fossiliferous rocks. Pale-colored lithology: its component rock has never yielded age-determined fossil and its age cannot be speculated by stratigraphical relationships. Carb.: Carboniferous; Pens.: Pennsylvanian; E.: Early; Lop.: Lopingian; Guad.: Guadalupian.

The belongingness of the subfamily Japonocapsinae Kozur follows O’Dogherty et al. (2009a). The generic classification of Permian albaillellarians employs recent studies by Xiao et al. (2020, 2021). Description of some non-taxonomic names (e.g. spine, spherical polycystine, three-segmented closed nassellarian) is also shown in this chapter, in addition to the taxonomic names.

\section{1 Taxonomic name}

Subclass RADIOLARIA Müller, 1858

Order ENTACTINARIA Kozur and Mostler, 1982

Family ENTACTINIIDAE Riedel, 1967
Genus Stigmosphaerostylus Rüst, 1892, emend Foreman, 1963

Type species Stigmosphaerostylus notabilis Rüst, 1892

Stigmosphaerostylus? sp.

Figs. 4.1, 4.14, 4.22

Remarks: The specimens are characterized by a spherical shell with some spicules. Stigmosphaerostylus is presented with a question mark because of the poor preservation.

Family EPTINGIIDAE Dumitrica, 1978 Genus Eptingium Dumitrica, 1978 
Type species Eptingium manfredi Dumitrica, 1978

Eptingium sp. cf. E. nakasekoi (Kozur and Mostler, 1994)

Fig. 5.48

Remarks: The specimen examined has two main spines which are three-bladed but not twisted, although one main spine seems to be lost. It closely resembles Eptingium nakasekoi Kozur and Mostler (Kozur and Mostler,1994).

Genus Xenorum Blome, 1984

Type species Xenorum largum Blome, 1984

\section{Xenorum? sp.}

Fig. 5.52

Remarks: The specimen possesses an outer layer consisting of polygonal pore frames with massive nodes. The form resembles the genus Xenorum Blome established by Blome (1984).

Family HINDEOSPHAERIDAE Kozur and Mostler, 1981

Genus Pseudostylosphaera Kozur and Mostler, 1981

Type species Pseudostylosphaera gracilis Kozur and Mock in Kozur and Mostler, 1981

Pseudostylosphaera sp. cf. P. japonica (Nakaseko and Nishimura, 1979)

Figs. 5.36, 5.38, 5.41, 5.44

Remarks: The specimens have two opposite polar spines that are moderately long, massive and three bladed. These characteristics closely resemble those of Pseudostylosphaera japonica Nakaseko and Nishimura described by Nakaseko and Nishimura (1979) although the preservation of the specimens is poor.

\section{Pseudostylosphaera sp.}

Figs. 5.37, 5.39, 5.40, 5.42, 5.43, 5.45, 5.55, 5.56

Remarks: The specimens have two opposite polar three-bladed spines. The characteristics closely resemble Pseudostylosphaera Kozur and Mostler established by Kozur and Mostler (1981).

\section{Pseudostylosphaera? sp.}

Fig. 5.5

Remarks: The specimen seems to have two opposite polar three-bladed spines and resembles Pseudostylosphaera. However, the detailed structure of the spines cannot be observed because of poor preservation. The specimen is therefore presented as Pseudostylosphaera with a question mark.

Order LATENTIFISTULARIA Caridroit, De Wever and Dumitrica, 1999

Family LATENTIFISTULIDAE Nazarov and Ormiston, 1983

Genus Latentifistula Nazarov and Ormiston, 1983
Type species Latentifistula crux Nazarov and Ormiston, 1983

\section{Latentifistula? sp.}

Figs. 4.10-4.13, 4.20, 4.21

Remarks: The specimens possess thick, spongy shells with three coplanar arms. The characteristics are similar to those of the genus Latentifistula Nazarov and Ormiston established by Nazarov and Ormiston (1983); however, they are presented as Latentifistula with the question mark because of poor preservation.

Family RUZHENCEVISPONGIDAE Kozur, 1980

Genus Scharfenbergia Won, 1983, emend. Kozur and Mostler (1989)

Type species Spongotripus concentricus Rüst, 1892

\section{Scharfenbergia? sp.}

Fig. 4.17

Remarks: The specimen is characterized by triangular spongy test with short arms originating from the corners of the triangular test. The form is similar to the genus Scharfenbergia Won established by Won (1983); however, the detailed structure cannot be observed because of the poor preservation. The specimen is therefore presented as Scharfenbergia with a question mark.

Family ORMISTONELLIDAE De Wever and Caridroit, 1984, emend. Dumitrica in De Wever et al., 2001

Genus Quadricaulis Caridroit and De Wever, 1986

Type species Quadricaulis femoris Caridroit and De Wever, 1986

\section{Quadricaulis? sp.}

Figs. 4.18, 4.25, 4.41, 4.45

Remarks: The specimens have a nonporous shell composed of a sphere with at least two arms. The characteristics resemble those of the genus Quadricaulis Caridroit and De Wever established by Caridroit and De Wever (1986); however, the detailed structure cannot be observed because of the poor preservation. The specimen is therefore presented as Quadricaulis with a question mark.

Genus Polyfistula Nazarov and Ormiston, 1984

Type species Polyfistula longiquitas Nazarov and Ormiston, 1984

Polyfistula sp. aff. P. hexalobata Nazarov and Ormiston, 1989

Figs. 4.16, 4.35

Remarks: The specimens have several horizontal slender arms originating from a platy disc. The characteristics are consistent with those of the genus Polyfistula Nazarov and Ormiston established by Nazarov and Ormiston (1984). The specimens are similar to Polyfistula hexalobata Nazarov and Ormiston in terms of having five horizontal 
slender rays. However, the specimens differ from Polyfistula hexalobata as they lack a clear vertical ray originating from the center of the platy disc.

\section{Polyfistula sp.}

Fig. 4.15

Remarks: The specimen has at least three horizontal slender arms originating from a platy disc. However, the exact number of rays and surface structure of the platy disc, which are the diagnostic characteristics of species level of the genus, cannot be observed.

\section{Family MUELLERITORTIIDAE Kozur, 1988} Genus Muelleritortis Kozur, 1988

Type species Emiluvia? cochleata Nakaseko and Nishimura, 1979

\section{Muelleritortis? sp.}

Fig. 5.51

Remarks: One twisted thick spine remained in the specimen. This type of spine is known in Muelleritortis cochleata (Nakaseko and Nishimura), which was originally described as Emiluvia? cochleata by Nakaseko and Nishimura (1979). Thus, the specimen may be a Muelleritortis cochleata that lost three arms. Meanwhile, some species of other genera, such as Pseudostylosphaera nazarovi (Kozur and Mostler) and Tritortis kretaensis Kozur and Krahl, also possess a twisted thick spine. The specimen is therefore identified as Muelleritortis Kozur with a question mark in this article.

Order NASSELLARIA Ehrenberg, 1875

Family RUESTICYRTIIDAE Kozur and Mostler, 1979 Genus Triassocampe Dumitrica, Kozur and Mostler, 1980 Type species Triassocampe scalaris Dumitrica, Kozur and Mostler, 1980

Triassocampe sp. cf. T. deweveri (Nakaseko and Nishimura, 1979)

Figs. 5.16, 5.29

Remarks: The specimens have a subcylindrical multi-segmented shell with dome-shaped cephalis. The segments are characterized by well-developed ridges. The characteristics resemble those of Triassocampe deweveri (Nakaseko and Nishimura) described by Nakaseko and Nishimura (1979). Because the specimens are partially broken, they are presented as the species with confer.

\section{Triassocampe sp.}

Fig. 5.10, 5.30, 5.34

Remarks: The specimens are characterized by a subcylindrical multi-segmented shell without an apical horn. In addition, pores are arranged in transverse rows for each segment. The characteristics resemble those of the genus Triassocampe Dumitrica, Kozur and Mostler (Dumitrica et al., 1980).
Triassocampe? sp.

Figs. 5.6, 5.11-5.15, 5.17-5.19, 5.24, 5.25, 5.28. 5.31, $5.33,5.35$

Remarks: The specimens have subcylindrical a multisegmented shell. Because of the poor preservation in an apical part and surface pores, they are presented as Triassocampe with a question mark.

Genus Annulotriassocampe Kozur and Mostler, 1994

Type species Annulotriassocampe campanilis Kozur and Mostler, 1994

\section{Annulotriassocampe sp.}

Figs. 5.26, 5.27

Remarks: The specimens have a long-conical shell. The segments are hoop-like and possess one ring of pores. These characteristics closely resemble those of the genus Annulotriassocampe Kozur and Mostler established by Kozur and Mostler (1994).

Genus Yeharaia Nakaseko and Nishimura, 1979

Type species Yeharaia elegans Nakaseko and Nishimura, 1979

\section{Yeharaia sp.}

Fig. 5.32

Remarks: The specimen has a well-developed apical horn. This characteristic closely resembles that of the genus Yeharaia Nakaseko and Nishimura established by Nakaseko and Nishimura (1979).

Family DIACANTHOCAPSIDAE O’Dogherty, 1994 Subfamily JAPONOCAPSINAE Kozur, 1984 Genus Japonocapsa Kozur, 1984

Type species Tricolocapsa? fusiformis Yao, 1979

Japonocapsa sp. aff. J. fusiformis (Yao, 1979) sensu Matsuoka (1983)

Fig. 9.5

Remarks: The specimen is characterized by a fusiform shell with a fourth segment that is dish-like and sparsely pored. Such characteristics resemble those of Japonocapsa fusiformis (Yao) originally described as Tricolocapsa? fusiformis by Yao (1979). Matsuoka (1983) described Japonocapsa sp. aff. J. fusiformis that has smaller basal appendage than Japonocapsa fusiformis. The specimen also has the small basal appendage and closely resembles Japonocapsa sp. aff. J. fusiformis.

Genus Striatojaponocapsa Kozur, 1984

Type species Tricolocapsa plicarum Yao, 1979

Striatojaponocapsa synconexa O’Dogherty, Goričan and Dumitrica, 2006

Fig. 10.1

Remarks: The specimen has a small basal appendage with a circular depression. It is closely similar to 
Striatojaponocapsa synconexa O’Dogherty, Goričan and Dumitrica studied by O'Dogherty et al. (2006) and Hatakeda et al. (2007).

\section{Striatojaponocapsa sp.}

\section{Fig. 11.1}

Remarks: The specimen is closely similar to Striatojaponocapsa conexa (Matsuoka) in outline of the shell. The specimen is presented as Striatojaponocapsa sp. because its surface structure and basal appendage, major criteria for identification, cannot be observed.

\section{Striatojaponocapsa? sp.}

Figs. 10.3, 10.5, 10.10

Remarks: The outline of the specimens resemble some species of Striatojaponocapsa, such as $S$. conexa and $S$. synconexa. The specimens are presented as Striatojaponocapsa with a question mark because of poor preservation.

\section{Genus Yaocapsa Kozur, 1984}

Type species Cyrtocapsa mastoidea Yao, 1979

\section{Yaocapsa? sp.}

Fig. 10.15

Remarks: The specimen has a large last segment. The genus Yaocapsa Kozur is also characterized by a large last segment. Meanwhile, the preservation of the specimen is very poor, and the segment cannot be clearly observed. The specimen is therefore presented as Yaocapsa with a question mark.

Family STICHOCAPSIDAE Haeckel, 1881

Genus Stichocapsa Haeckel, 1881

Type species Stichocapsa jaspidea Rüst, 1885

"Stichocapsa" sp. E sensu Baumgartner et al. (1995) Fig. 10.2

Remarks: The specimen has spherical cephalis without apical horn and truncate-conical thorax and abdomen. The large last segment can be observed, although the last segment is partially broken. The characteristics are similar those of "Stichocapsa" sp. E sensu Baumgartner et al. (1995). Stichocapsa Haeckel is currently considered as nomen dubium (O’Dogherty et al., 2009a), so the generic name is presented as Stichocapsa with double quotations.

Family EUCYRTIDIELLIDAE Takemura, 1986 Genus Eucyrtidiellum Baumgartner, 1984

Type species Eucyrtidium? unumaensis Yao, 1979

Eucyrtidiellum sp. cf. E. unumaense (Yao, 1979) Fig. 10.16

Remarks: The specimen is characterized by having a small cephalis with apical horn and truncate-conical thorax. The characteristics are similar as those of Eucyrtidiellum unumaense (Yao), although some structures (e.g. surface, fourth segment) were lost.

\section{Eucyrtidiellum gunense Cordey, 1998}

Fig. 6.11

Remarks: Eucyrtidiellum gunense Cordey has stout and longer apical horn in the cephalis with conical thorax (Cordey, 1998; Goričan et al., 2006). The characteristics of the specimen closely resemble those of Eucyrtidiellum gunense.

\section{Eucyrtidiellum sp.}

Figs. 6.3, 6.6, 6.12

Remarks: The specimens have a small cephalis and dome-shaped thorax. These characteristics are similar to those of the genus Eucyrtidiellum Baumgartner established by Baumgartner (1984).

Family PSEUDODICTYOMITRIDAE Pessagno, 1977b Genus Mizukidella O’Dogherty, Goričan and Gawlick, 2017

Type species Dictyomitrella? kamoensis Mizutani and Kido, 1983

\section{Mizukidella? sp.}

Fig. 9.31

Remarks: Mizukidella O’Dogherty, Goričan and Gawlick is characterized by a multicyrtid conical to subcylindrical shell having nodose circumferential ridges (O'Dogherty et al., 2017). The specimen also has nodose circumferential ridges and resembles some species of the genus, such as Mizukidella kamoensis (Mizutani and Kido), a type species of the genus. However, the preservation is poor and other characteristics cannot be observed, so that it is presented as the genus with a question mark.

Family PARVICINGULIDAE Pessagno, 1977a Genus Takemuraella O’Dogherty, Goričan and Gawlick, 2017

Type species Triversus japonicus Takemura, 1986

Takemuraella sp. cf. T. japonica (Takemura, 1986) Fig. 10.19

Remarks: Takemuraella japonica (Takemura), originally described as Triversus japonicus by Takemura (1986), has a shell composed of small cephalis and conical thorax with irregularly distributed pores and pore frames (Takemura, 1986; O'Dogherty et al., 2017). The characteristics of the specimen is similar to the species, although the surface is poorly preserved.

Family ARCHAEODICTYOMITRIDAE Pessagno, 1976

Genus Archaeodictyomitra Pessagno, 1976

Type species Archaeodictyomitra squinaboli Pessagno, 1976

\section{Archaeodictyomitra sp.}

Figs. 10.18, 10.20, 12.11

Remarks: The specimens have linearly arranged, 
continuous costae with pores in a single row between the costae. They are similar to species of the genus Archaeodictyomitra Pessagno established by Pessagno (1977a).

\section{Family HSUIDAE Pessagno and Whalen, 1982} Genus Hsuum Pessagno, 1977a

Type species Hsuum cuestaensis Pessagno, 1977a

\section{Hsuum maxwelli Pessagno, 1977a}

Figs. 9.25, 10.17

Remarks: The specimens are characterized by discontinuous, diverging costae. In particular, the cephalis of the specimens has the clear costae and lacks an apical horn. Hsuum maxwelli Pessagno has these characteristics (Pessagno, 1977a), whereas other major species of Hsuum Pessagno lack clear costae in the cephalis and/or have an apical horn.

\section{Genus Parahsuum Yao, 1982}

Type species Parahsuum simplum Yao, 1982

\section{Parahsuum simplum Yao, 1982}

Fig. 6.16

Remarks: According to some studies (e.g. Yao, 1982; Hori and Yao, 1988), Parahsuum simplum Yao possesses a conical shell with smooth-edged, continuous, longitudinal costae and differs from other species of Parahsuum Yao in having shorter, smaller apical horn. The specimen has the characteristics in the shell.

\section{Parahsuum sp. cf. P. simplum Yao, 1982}

Fig. 6.15

Remarks: The specimen possesses a conical shell with smooth-edged, continuous, longitudinal costae. Although these characteristics are similar to those of Parahsuum simplum, the shell of the specimens were partially broken and thereby the distinguished characteristics (e.g. shorter, smaller apical horn) cannot be observed.

\section{Parahsuum transiens Hori and Yao, 1988}

Figs. 6.13, 6.14

Remarks: The specimens have a long, conical shell with smooth-edged, continuous, longitudinal costae. The distal portion of the shell bears weak circumferential ridges. These characteristics closely resemble those of Parahsuum transiens Hori and Yao described by Hori and Yao (1988).

\section{Parahsuum? sp.}

Figs. 6.23, 6.26

Remarks: The specimen has linearly arranged, continuous costae. Parahsuum has these characteristics (Yao, 1982). However, the pores are unclear because of the poor preservation. Other genera of Hsuidae Pessagno and Whalen, such as Hsuum Pessagno, is also characterized by linearly arranged, continuous costae and distinguished from Parahsuum by features of the pores. Thus, the specimens are represented as Parahsuum with a question mark.

Family WILLIRIEDELLIDAE Dumitrica, 1970 Genus Williriedellum Dumitrica, 1970

Type species Williriedellum crystallinum Dumitrica, 1970

Williriedellum? marcucciae Cortese, 1993

Fig. 11.2

Remarks: The specimen seems to have an oval shell with its surface cut by numerous polygonal depressing facets. The outline of the shell is closely similar to Williriedellum? marcucciae Cortese described as Williriedellum? marcuccii by Cortese (1993).

Order SPUMELLARIA Ehrenberg, 1875

Family PANTANELLIDAE Pessagno, 1977b

Genus Pantanellium Pessagno, 1977a

Type species Pantanellium riedeli Pessagno, 1977a

\section{Pantanellium? sp.}

Figs. 6.35-6.37

Remarks: The specimens have a subspherical shell and possibly two polar spines. They are similar to some species of the genus Pantanellium Pessagno described by Pessagno (1977a).

Genus Trillus Pessagno and Blome, 1980 Type species Trillus seidersi Pessagno and Blome, 1980

\section{Trillus? sp.}

Figs. 6.41

Remarks: The specimen has bipolar massive spines characterized by wide ridges and wide grooves. Such characteristics are known in species of genus Trillus Pessagno and Blome, such as Trillus elkhornensis Pessagno and Blome (Pessagno and Blome, 1980), so this specimen may be the species.

Family CAPNUCHOSPHAERIDAE De Wever, 1979 in De Wever et al., 1979

Genus Capnuchosphaera De Wever, 1979 in De Wever et al., 1979

Type species Capnuchosphaera triassica De Wever, 1979 in De Wever et al., 1979

\section{Capnuchosphaera? sp.}

Fig. 5.53

Remarks: The specimen has a spongy shell with one conical arm and two arms possibly broken. Although the preservation is very poor, the outline is similar to some species of the genus Capnuchosphaera De Wever established by De Wever et al. (1979). Here, the specimen is represented as Capnuchosphaera with a question mark because the very poor preservation. 
Family EMILUVIDAE Dumitrica, 1995

Genus Emiluvia Foreman, 1973

Type species Emiluvia chica Foreman, 1973

\section{Emiluvia? sp.}

Fig. 12.14

Remarks: The specimen possesses a rectangle shell with at least two spines. It seems to be broken specimen of Emiluvia Foreman, which has a rectangle shell with four spines, one at each corner arranged to form a cross (Foreman, 1973). The specimen is represented as Emiluvia with a question mark because the preservation condition.

Nassellaria gen. et sp. indet.

Figs. 9.3, 9.4

Remarks: The specimens seem to conical shell. However, they lack detailed structure. One specimen (Fig. 9.3) looks like closed nassellarian; however, the closed part is not preserved. Another specimen (Fig. 9.4) slightly resembles multi-segmented nassellarian in shell outline; however, segments on the surface cannot be observed. Consequently, these specimens are represented as Nassellaria gen. et sp. indet.

Order ALBAILLELLARIA Deflandre, 1953 Family FOLLICUCULLIDAE Ormiston and Babcock, 1979

Genus Parafollicucullus Holdsworth and Jones, 1980, emend. Xiao and Suzuki in Xiao et al. (2021)

Type species Parafollicucullus fusiformis Holdsworth and Jones, 1980

Parafollicucullus sp. cf. P. monacanthus (Ishiga and Imoto, 1982) in Ishiga et al., 1982

Fig. 4.44

Remarks: The specimen has a dorsal wing and lacks a ventral wing. Such characteristics are known in Parafollicucullus monacanthus (Ishiga and Imoto) (Ishiga et al., 1982). The pseudoabdomen is partially broken.

Genus Pseudoalbaillella Holdsworth and Jones, 1980, emend. Xiao and Suzuki in Xiao et al. (2021)

Type species Pseudoalbaillella scalprata Holdsworth and Jones, 1980

Pseudoalbaillella japonica Nestell and Nestell, 2020

Figs. 4.2-4.6, 4.8, 4.9, 4.27, 4.28, 4.31-4.33

Remarks: The specimens have a triangular pseudothorax and short pseudoabdomen. Such structures are known in Pseudoalbaillella japonica Nestell and Nestell described by Nestell and Nestell (2020).

Pseudoalbaillella postscalprata Ishiga, 1983

Figs. 4.7, 4.29, 4.30

Remarks: The specimens are slightly similar to Pseudoalbaillella japonica; however, they have a longer pseudoabdomen. Such characteristics are known in Pseudoalbaillella postscalprata Ishiga, which is considered as a progeny species of Pseudoalbaillella japonica (Ishiga, 1983).

\section{Pseudoalbaillella? sp.}

Fig. 4.34

Remarks: The specimen has an apical cone and pseudoabdomen. This outline is known in Pseudoalbaillella Holdsworth and Jones and similar genera such as Parafollicucullus Holdsworth and Jones. The specimen is therefore presented as Pseudoalbaillella with a question mark.

Genus Ishigaconus Kozur and Mostler, 1989

Type species Follicucullus scholasticus Ormiston and Babcock, 1979

Ishigaconus scholasticus (Ormiston and Babcock, 1979)

Fig. 4.50

Remarks: The specimen is characterized by a conical shell without wing(s) and segmentation(s). Such shell is known in Ishigaconus scholasticus (Ormiston and Babcock), which was originally described as Follicucullus scholasticus by Ormiston and Babcock (1979).

\section{2 Non-taxonomic name}

\section{Arm of Latentifistularia gen. et sp. indet.}

Fig. 4.42

Remarks: The form of the specimen is rod-like, and one end is branched. The branched end is composed of at least four platy parts. This is possibly arm of any taxa of Latentifistularia Caridroit, De Wever and Dumitrica, although appropriate species is unknown.

Short form of Parafollicucullus fusiformis Holdsworth and Jones, 1980, sensu Ito et al., 2015

Fig. 4.43

Remarks: The specimen has skirt-like short pseudoabdomen seems to lack most of its pseudoabdomen. Ito et al. (2015) described the type of form as a short form of Parafollicucullus fusiformis Holdsworth and Jones.

Short form of Parafollicucullus monacanthus (Ishiga and Imoto, 1982) in Ishiga et al., 1982 sensu Ito et al., 2015

Figs. 4.46-4.49

Remarks: The specimens have a dorsal wing and lack a ventral wing, sharing the characteristics of Parafollicucullus monacanthus (Ishiga and Imoto). They have skirt-like short pseudoabdomen and seem to lack most of their pseudoabdomen. Ito et al. (2015) described this type of form as a short form.

Spine A2 of Sugiyama (1997)

Fig. 5.50

Remarks: The specimen is rod-like, curved spine. 
Sugiyama (1997) speculated that Spine A2 is possibly derived from Oertlispongus inaequispinosus Dumitrica, Kozur and Mostler or Flexispongus cornuhovis Larm.

\section{Grooved spine}

Figs. 5.8, 5.9, 6.38-6.40

Remarks: The specimens are grooved spines. The spines are slightly curved. Several taxa of radiolarian orders in the Paleozoic-Cenozoic, such as Entactinaria Kozur and Mostler, Spumellaria Ehrenberg and Nassellaria Ehrenberg, possess grooved spines (e.g. De Wever et al., 2001).

\section{Multi-segmented nassellarian}

Figs. 5.7, 6.17-6.21, 6.24, 6.25, 6.27-6.34, 9.23, 9.24, $9.32,10.21-10.24,11.5,12.8,12.10,12.12,12.13,13.2$, $13.3,13.8,13.24$

Remarks: The specimens are characterized by multisegmented tower-like shell. Such radiolarians are generally known in the Mesozoic-Cenozoic nassellarian (e.g. De Wever et al., 2001).

\section{Three-segmented closed nassellarian}

Figs. 6.4, 6.5, 6.7-6.10, 7.1, 7.2, 7.4, 9.1, 9.2, 9.6-9.11, 9.13-9.22, 9.27-9.30, 10.4, 10.6, 10.9, 10.11-10.14, 11.3, $11.6,11.7,12.1-12.6$

Remarks: Three-segmented closed nassellarian has a spindle-shaped shell composed of cephalis, thorax and abdomen. Such nassellarians are known mainly in the Family Williriedellidae Dumitrica. Representative genera of the family are Williriedellum Dumitrica, Zhamoidellum Dumitrica, Hemicryptocapsa Tan Sin Hok, Holocryptocanium Dumitrica and Cryptamphorella Dumitrica. Japonocapsa Kozur and Striatojaponocapsa Kozur belonging to the Family Syringocapsidae also have these characters. The specimens are possibly identified as any of the genera.

\section{Closed nassellarian}

Figs. 6.1, 6.2 , 7.3, 7.5, 7.6, 8.1, 8.2, 8.5, 8.8, 9.12, 9.26, $11.4,11.8-11.11,12.7,12.9$

Remarks: Closed nassellarian has spindle form which a distal end is closed. They differ from three-segmented closed nassellarian in unobservable segmentation in the shell. However, a specimen identified as closedend nassellarian could be three-segmented closed nassellarian that lost segmentation structure because of poor preservation, i.e. closed-end nassellarian includes three-segmented nassellarian.

\section{Spherical polycystine}

Figs. 4.23, 4.26, 4.38-4.40, 5.1-5.3, 5.20-5.23, 6.42, 6.43, 8.3, 8.4, 8.6, 8.7, 12.15, 13.1, 13.4-13.7, 13.9-13.13, $13.15,13.20-13.22,13.25-13.32,13.34-13.36$

Remarks: As its name indicates, spherical polycystine possesses spherical shell. Radiolarian having a spherical shell is known in the Orders Entactinaria and Spumellaria.
A specimen of the Order Nassellaria observed from distal side also looks spherical-shaped shell.

Spherical polycystine, i.e. Entactinaria, Spumellaria or Nassellaria, occurred in the Paleozoic to recent (e.g. De Wever et al., 2001), so that it is not valuable for age assignment.

\section{Spine-bearing spherical polycystine}

Figs. 5.54, 13.14, 13.16-13.18

Remarks: Specimens having spherical shell with spines are called as spine-bearing spherical polycystine in this article. Such radiolarians are known in some taxa of the orders Entactinaria and Spumellaria.

Entactinaria and Spumellaria occurred in the Paleozoic to recent (e.g. De Wever et al., 2001), so that it is not valuable for age assignment.

\section{Three-coplaner-spine-bearing spherical polycystine} Figs. 5.4, 5.46, 5.47, 5.49, 13.19, 13.33

Remarks: Specimens having spherical shell with three coplaner spines are called as three-coplaner-spine-bearing spherical polycystine in this article. Such radiolarians are known in some taxa of Order Spumellaria.

Spumellaria occurred mainly in the Mesozoic to recent (e.g. De Wever et al., 2001), so that it is not valuable for age assignment.

Acknowledgments: The author wishes to thank Dr. MUTO Shun (Geological Survey of Japan, AIST) for the comment on age assignments of the conodonts from the Jurassic accretionary complex in the present and previous studies; Dr. HARA Hidetoshi (Geological Survey of Japan, AIST) for the editing the manuscript and constructive comments on the article's composition; Prof. MATSUOKA Atsushi (Niigata University) for careful review and suggestive comments mainly on identification and age assignments of Triassic and Jurassic radiolarians that improved greatly this manuscript.

\section{References}

Aita, Y. (1987) Middle Jurassic to Lower Cretaceous radiolarian biostratigraphy of Shikoku with reference to selected sections in Lombardy Basin and Sicily. The Science Reports of the Tohoku University, Series 2: Geology, 58, 1-91.

Aono, H. (1985) Geologic structure of the Ashio and Yamizo Mountains with special reference to its tectonic evolution. Science reports of the Institute of Geoscience, University of Tsukuba, Section B, Geological Sciences, 6, 21-57.

Arakawa, R. (1986) Upper Paleozoic and Mesozoic strata in the southeastern part of the Ashio Mountains. Bulletin of the Tochigi Prefectural Museum, no. 3, 1-37. (in Japanese with English abstract)

Arakawa, R. (1997) Jurassic radiolarian succession from the siliceous mudstone in the Kuzuu area of the 
Ashio terrane, central Japan. Bulletin of the Tochigi Prefectural Museum, no. 14, 1-19. (in Japanese with English abstract)

Arakawa, R. (1998) Middle Jurassic radiolarian assemblages from Manganese dioxide nodules, Kuzuu area of Ashio terrane, central Japan. Bulletin of the Tochigi Prefectural Museum, no. 15, 51-76. (in Japanese with English abstract)

Baumgartner, P. O. (1984) A Middle Jurassic-Early Cretaceous low latitude radiolarian zonation based on unitary associations and age of Tethyan radiolarites. Eclogae Geologicae Helvetiae, 77, 729-841.

Baumgartner, P. O., O’Dogherty, L., Goričan, Š., Dumitrica-Jud, R., Dumitrica, P., Pillevuit, A., Urquhart, E., Matsuoka, A., Danelian, T., Bartolini, A., Carter, E. S., De Wever, P., Kito, N., Marcucci, M. and Steiger, T. (1995) Radiolarian catalogue and systematics of Middle Jurassic to Early Cretaceous Tethyan genera and species. In Baumgartner, P. O., O’Dogherty, L., Goričan, Š., Urquhart, E., Pillevuit, A. and De Wever, P., eds., Middle Jurassic to Lower Cretaceous Radiolaria of Tethys: Occurrences, Systematics, Biochronology. Mémoires de Géologie (Lausanne), 23, 37-685.

Blome, C. (1984) Upper Triassic Radiolaria and radiolarian zonation from western North America. Bulletins of American Paleontology, 85, 1-88.

Caridroit, M. and De Wever, P. (1986) Some late Permian radiolarians from pelitic rocks of the Tatsuno Formation (Hyogo Prefecture), southwest Japan. Marine Micropaleontology, 11, 55-90.

Caridroit, M., De Wever, P. and Dumitrica, P. (1999) A new order, a new family and a new genus of Paleozoic Radiolaria: Latentifistularia, Cauletellidae and Cauletella. Comptes Rendus de l'Académie des Sciences de Paris, Série IIA-Sciences de la Terre et des Planètes, 329, 603-608.

Carter, E. S., Goričan, Š., Guex, J., O’Dogherty, L., De Wever, P., Dumitrica, P., Hori, R. S., Mastuoka, A., and Whalen, P. A. (2010) Global radiolarian zonation for the Pliensbachian, Toarcian and Aalenian. Palaeogeography, Palaeoclimatology, Palaeoecology, 297, 401-419.

Chen, Y., Krystyn, L., Orchard, M. J., Lai, X. L. and Richoz, S. (2016) A review of the evolution, biostratigraphy, provincialism and diversity of Middle and early Late Triassic conodonts. Papers in Palaeontology, 2, 235-263.

Chiari, M., Marcucci, M. and Prela, M. (2002) New species of Jurassic radiolarians in the sedimentary cover of ophiolites in the Mirdita area, Albania. Micropaleontology, 48 (supplement no. 1), 61-87.

Conodont Research Group (1972) Conodonts at the Permian-Triassic boundary in Japan. -Conodonts from the basal part of the Adoyama Formation-. The Journal of the Geological Society of Japan, $\mathbf{7 8}$, 355-368. (in Japanese with English abstract)
Conodont Research Group (1974) Conodonts at the Permian-Triassic boundary in Japan. - Stratigraphy and faunas of the Nabeyama and Adoyama formations in Karasawa area, southeast Ashio Mountains-. Earth Science (Chikyu Kagaku), 28, 86-98. (in Japanese with English abstract)

Cordey, F. (1998) Radiolaires des complexes d'accrétion de la Cordillére Canadienne (Colombie-Britannique). Commission Géologique du Canada Bulletin, no. 509, $1-209$.

Cortese, G. (1993) Radiolarian biostratigraphy of the Tuscan Cherts (Tuscan Succession) from Val di Lima, Tuscany, Northern Apennines. Paleopelagos, 3, 165-185.

De Wever, P. and Caridroit, M. (1984) Description of some new Latentifistulidea (polycystines Radiouria) from Paleozoic of Japan. Revue de Micropaléonologie, 27, 98-106.

De Wever, P., Dumitrica, P., Caulet, J. P., Nigrini, C. and Caridroit, M. (2001) Radiolarians in the Sedimentary Record. Gordon and Breach Science Publishers, Singapore, 533p.

De Wever, P., Sanfilippo, A., Riedel, W. R. and Gruber, G. (1979) Triassic radiolarians from Greece, Sicily and Turkey. Micropaleontology, 25, 75-110.

Deflandre, G. (1953) Radiolaires fossiles, In Grassé, P. P., Ed., Traité de Zoologie. Masson, Paris, 389-436.

Dumitrica, P. (1970) Cryptocephalic and cryptothoracic Nassellaria in some Mesozoic deposits of Romania. Revue roumaine de Géologie, Géophysique et Géographie (série Géologie), 14, 45-124.

Dumitrica, P. (1978) Family Eptingiidae n. fam., extinct Nassellaria (Radiolaria) with sagittal ring. Dari de seama ale sedintelor, Institutul de Geologie si Geofi zica, Bucuresti, 64, 27-38.

Dumitrica, P. (1995) Systematic framework of Jurassic and Cretaceous Radiolaria. Mémoires de Géologie (Lausanne), 23, 19-35.

Dumitrica P., Kozur H. and Mostler H. (1980) Contribution to the radiolarian fauna of the Middle Triassic of the Southern Alps. Geologisch Paläontologische Mitteilungen Innsbruck, 10, 1-46.

Dumitrica-Jud, R. (1995) Early Cretaceous radiolarian biostratigraphy of Umbria-Marche Apennines (Italy), Southern Alps (Italy and Switzerland) and Hawasina Nappes (Oman). Mémoires de Géologie (Lausanne), 23, 751-790.

Editorial team of Omama Town's history* (1996) Omama Town's History, Basic Data VIII: Geography and Geology of Omama Town*. Publication committee of Omama Town's history*, Omama Town (current administrative division: Kiryu City), Gunma.

Ehrenberg C. G. (1875) Fortsetzung der mikrogeologischen Studien als Gesammt-Uebersichtder mikroskopischen Palaontologie gleichartig analysirter Gebirgsarten der Erde, mit specieller Rucksicht aufden PolycystinenMergel von Barbados. Abhandlungen der königlichen 
preussichen Akademie der Wissenschaften zu Berlin, $1-225$.

Foreman, H. P. (1963) Upper Devonian Radiolaria from the Huron member of the Ohio shale. Micropaleontology, 9, 267-304.

Foreman, H. P. (1973) Radiolaria from DSDP Leg 20. In Heezen, B. C., MacGregor, I. D., Foreman, H. P., Forristall, G., Hekel, H., Hesse, R., Hoskins, R. H., Jones, E. J. W., Kaneps, A. G., Krasheninnikov, V. A., Okada, H. and Ruef, M. H., Eds., Initial Reports of the Deep Sea Drilling Project, 20, Washington, U.S. Government Printing Office, 249-305.

Fujimoto, H. (1960) Carboniferous System of Japan. Geological Survey of Japan. 65p.

Fujimoto, H. (1961) Explanatory text of the Geological map of Japan, Scale 1:50,000, Tochigi. Geological Survey of Japan. 62p. (in Japanese with English Summary)

Geological Survey of Japan, AIST (2018) Seamless digital geological map of Japan 1: 200,000. January 26, 2018 version. Geological Survey of Japan, AIST. https:// gbank.gsj.jp/seamless/v2full/ (Accessed:2018-1-26)

Goričan, Š., Carter, E. S., Dumitrica, P., Whalen, P. A., Hori, R. S., De Wever, P., O’Dogherty, L., Matsuoka, A. and Guex, J. (2006) Catalogue and Systematics of Pliensbachian, Toarcian and Aalenian Radiolarian Genera and Species. ZRC Publishing, Scientific Research Centre of the Slovenian Academy of Sciences and Arts, Ljubljana, 446 p.

Goto, N. (1975) New find of the Permian and Triassic fish Fossils in Japan: On the dermal denticles and teeth of fishes discovered from Karasawa area, southeast Asio Mountains. Earth Science (Chikyu Kagaku), 29, 72-74. (in Japanese with English abstract)

Goto, N. (1984) Discovery of a petalodont shark tooth from the Nabeyama Formation (Middle Permian) in Kuzuu, Tochigi Prefecture, central Japan. Earth Science (Chikyu Kagaku), 38, 139-142. (in Japanese)

Goto, N. (1994) Palaeozoic and early Mesozoic fish faunas of the Japanese Islands. The Island Arc, 3, 247-254.

Haeckel, (1881) Entwurf eines Radiolarien-Systems auf Grund von Studien der Challenger-Radiolarien. Jenaische Zeitschrift für Naturwissenschaft, 15, 418-472.

Harada, S. (1886) Geologic outline of the Ashio Copper Mine*. Briefing Report of Geology* (Chishitsu Gaiho), 192-197. (in Japanese)

Hatakeda, K., Suzuki, N. and Matsuoka, A. (2007) Quantitative morphological analyses and evolutionary history of the Middle Jurassic polycystine radiolarian genus Striatojaponocapsa Kozur. Marine Micropaleontology, 63, 39-56.

Hatori, H. (1965) Stratigraphic studies in the southeastern part of the Ashio Massif, Tochigi Prefecture. The Journal of the Geological Society of Japan, 71, 247-256. (in Japanese with English abstract)

Hattori, I. (1987) Jurassic radiolarian fossils from the Nanjo Massif, Fukui Prefecture, central Japan.
Bulletin of Fukui City Museum of Natural History, 34, 29-101. (in Japanese with English abstract)

Hayasaka, I. (1926) On a new Carboniferous brachiopod fauna from the Ashio Mountains, Japan. Proceedings of the Imperial Academy, 2, 551-553.

Hayasaka, I. (1944) On the geological age of the brachiopod beds in the Vicinity of Nabeyama, Totigi Prefecture. The Journal of the Geological Society of Japan, 51, 154-156. (in Japanese)

Hayashi, S. (1963) On the conodonts newly discovered from the Ashio Mountains, central Japan. Earth Science (Chikyu Kagaku), 68, 9-12. (in Japanese with English abstract)

Hayashi, S. (1964) Discovery of conodonts from "Narutakite". The Journal of the Geological Society of Japan, 70, 596. (in Japanese)

Hayashi, S. (1968a) The Permian conodonts in chert of the Adoyama Formation, Ashio Mountains, central Japan. Earth Science (Chikyu Kagaku), 22, 63-77. (in Japanese with English abstract)

Hayashi, S. (1968b) Redescription of the new forms proposed in "The Permian conodonts in chert of the Adoyama Formation, Ashio Mountains, central Japan," 1968 by Shingo HAYASHI. Earth Science (Chikyu Kagaku), 22, 305. (in Japanese with English abstract)

Hayashi, S. (1971) Conodonts from the Nabeyama Formation, Kuzuu District, Tochigi Prefecture, Japan. Earth Science (Chikyu Kagaku), 25, 251-257. (in Japanese with English abstract)

Hayashi, S. and Hasegawa, Y. (1981) Chichibu System in the Ashio belt: Macrofossil- and conodont-based age (Part 2)*. Studies on Late Mesozoic Tectonism in Japan, no. 3, 233-249. (in Japanese with English abstract)

Hayashi, S., Iijima, S., Ishii, I., Nakajima, T., Sawaguchi, H., Tanaka, H. and Yoshida, T. (1990) Late Paleozoic to Mesozoic formations in the southwestern Ashio Mountains. Bulletin of the Gunma Prefectural Museum of History, no. 11, 1-34. (in Japanese with English abstract)

Henderson, C. M. (2018) Permian conodont biostratigraphy. In Lucas, S. G. and Shen, S. Z., Eds., The Permian Time Scale, Geological Society, London, Special Publication, 450, 119-142.

Holdsworth, B. K. and Jones, D. L. (1980) Preliminary radiolarian zonation for late Devonian through Permian time. Geology, 8, 281-285.

Hori, N. (1999) Latest Jurassic radiolarians from the northeastern part of the Torinoko Block, Yamizo Mountains, central Japan. Science reports of the Institute of Geoscience, University of Tsukuba, Section B, Geological Sciences, 20, 47-114.

Hori, R. (1990) Lower Jurassic radiolarian zones of SW Japan. Transactions and Proceedings of Palaeontological Society of Japan, New Series, no. 159, 562-586. 
Hori, R. S. (1997) The Toarcian radiolarian event in bedded cherts from southeastern Japan. Marine Micropaleontology, 30, 159-169.

Hori, R. and Yao, A. (1988) Parahsuum (Radiolaria) from the Lower Jurassic of the Inuyama area, central Japan. Journal of Geosciences, Osaka City University, 31, 47-61.

Hujimoto, H. (1938) On the Fusulina-Limestone in the Asio Mountainland (Preliminary Report). The Journal of the Geological Society of Japan, 45, 379-382. (in Japanese with English abstract)

Hull, D. M. (1997) Upper Jurassic Tethyan and Southern Boreal radiolarians from western North America. Micropaleontology, 43 (supplement no. 2), 1-202.

Igo, Hh. and Nishimura, H. (1984) The Late Triassic and Early Jurassic radiolarian biostratigraphy in the Karasawa, Kuzuu town, Tochigi Prefecture (Preliminary report). Bulletin of Tokyo Gakugei University. Series IV, 36, 173-193. (in Japanese with English abstract)

Igo, Hh., Aoki, R. and Hosoi, S. (1976) On the Boundary between the Permian and Triassic formations in the Eastern Part of the Kuzu Area, Tochigi Prefecture. Bulletin of Tokyo Gakugei University. Series IV, 28, 226-236. (in Japanese with English abstract)

Igo, Hy. (1964) Fusulinids from the Nabeyama Formation (Permian) Kuzu, Tochigi Prefecture, Japan. Memoirs of Mejiro Gakuen Woman's Junior College, 1, 1-28.

Igo, Hy. (1985) Triassic limestone from Fukabori, upper stream of the Akiyama River, Ashio Mountains*. A comprehensive research on the Joetsu and Ashio belts* (Sogo Kenkyu, Joetsu-Tai, Ashio-Tai), no. 2, 99-102. (in Japanese)

Igo, Hy. and Igo, Hh. (1977) Upper Permian fusulinaceans contained in the pebbles of the basal conglomerate of the Adoyama Formation, Kuzu, Tochigi Prefecture, Japan. Transactions and Proceedings of the Palaeontological Society of Japan, New Series, no. 106, 89-99.

Igo, Hy., Koizumi, H. and Kaniwa, T. (2000) A Permian Rugosa Yatsengia kuzuensis, from north of Kiryu in the Ashio mountains, Gunma Prefecture, Japan. Bulletin of the National Science Museum, Series C, Geology and Paleontology, 26, 79-86.

Ishiga, H. (1983) Morphological change in the Permian Radiolaria, Pseudoalbaillella scalprata in Japan. Transactions and Proceedings of the Palaeontological Society of Japan, New Series, no. 129, 1-8.

Ishiga, H. (1986) Late Carboniferous and Permian radiolarian biostratigraphy of southwest Japan. Journal of Geosciences, Osaka City University, 29, 89-100.

Ishiga, H. (1990) Paleozoic radiolarians. In Ichikawa, K., Mizutani, S., Hara, I. and Yao, A., eds, Pre-Cretaceous Terranes of Japan. Publication of IGCP Project No. 224: Pre-Jurassic Evolution of Eastern Asia. IGCP Project 224, Osaka, Japan, 285-295.
Ishiga, H., Kito, T. and Imoto, N. (1982) Middle Permian radiolarian assemblages in the Tamba District and an adjacent area, Southwest Japan. Earth Science (Chikyu Kagaku), 36, 272-281.

Isogawa, J., Aita, Y. and Sakai, T. (1998) Early Triassic radiolarians from the bedded chert in the Minowa quarry, Kuzuu Town, Tochigi Prefecture. News of Osaka Micropalaeontologists (NOM), Special Volume, no. 11, 81-93. (in Japanese with English abstract)

Isozaki, Y., Maruyama, S. and Furuoka, F. (1990) Accreted oceanic materials in Japan. Tectonophysics, 181, 179-205.

Ito, T. (2019) A report of Permian, Triassic, and Jurassic radiolarian occurrences from the Ashio terrane in the Hachioji Hills, eastern Gunma Prefecture, central Japan. Bulletin of the Geological Survey of Japan, 70, 225-247.

Ito, T. (2020a) A Cisuralian (early Permian) radiolarian assemblage and a new species of Latentibifistula Nazarov and Ormiston from central Japan. Revue de. Micropaléontologie, 66, 100407.

Ito, T. (2020b) Radiolarian age of Triassic striped chert within the Jurassic accretionary complex of the Ashio terrane in the Ashikaga area, Tochigi Prefecture, central Japan. Bulletin of the Geological Survey of Japan, 71, 297-312.

Ito, T. (2021) Geology and correlation of Jurassic accretionary complex in the Ashio Mountains, central Japan: Investigation on the Kiryu and Ashikaga District (Quadrangle series 1:50,000). Bulletin of the Geological Survey of Japan, 72, 201-285. (in Japanese with English abstract).

Ito, T. and Nakamura, Y. (2021) Biotite granodiorite of the Ashikaga Body and contact metamorphic rock in Nagusa, Ashikaga City, Tochigi Prefecture, central Japan. Bulletin of the Geological Survey of Japan, 72, 383-396. (in Japanese with English abstract)

Ito, T., Feng, Q. L. and Matsuoka, A. (2015) Taxonomic significance of short forms of middle Permian Pseudoalbaillella Holdsworth and Jones, 1980 (Follicucullidae:Radiolaria). RevuedeMicropaléontologie, 58, 3-12.

Ito, T., Nakamura, K., Hinohara, T. and Kurihara, T. (2021a) Occurrence report of Triassic and Jurassic radiolarians from the Jurassic accretionary complexes of the Ashio belt in eastern Mt. Narukami, Ashio Mountains, central Japan. Bulletin of the Geological Survey of Japan, 72, 345-358.

Ito, T., Suzuki, N. and Sashida, K. (2021b) Radiolarians and foraminifers from the Omama Complex (Jurassic accretionary complex of the Ashio terrane) in the Ashio Mountains, central Japan. Bulletin of the Geological Survey of Japan, 72, 359-370. (in Japanese with English abstract)

Kamata, Y. (1995) Early Triassic radiolarians from black siliceous shale and black chert in the Kuzu area of 
the Ashio terrane, central Japan. Fossils (Kaseki), 59, 23-31. (in Japanese with English abstract)

Kamata, Y. (1996) Tectonostratigraphy of sedimentary complex in the southern part of the Ashio terrane, central Japan. Science Reports of the Institute of Geoscience, University of Tsukuba, Section B, Geological Sciences, 17, 71-107.

Kamata, Y. (1997a) Reconstruction of chert-clastic sequence of the Ashio terrane in the Kuzu area, central Japan. The Journal of the Geological Society of Japan, 103, 343-356. (in Japanese with English abstract)

Kamata, Y. (1997b) Late Permian to Late Triassic radiolarians from a float of the sandstone and chert breccia in the Ashio Mountains (Preliminary report). News of Osaka Micropalaeontologists (NOM), Special Volume, no. 10, 97-107. (in Japanese with English abstract)

Kamata, Y. (1999) Lower Triassic (Spathian) radiolarians from the Kuzu area (Tochigi Prefecture, central Japan). Geodiversitas, 21, 657-673.

Kamata, Y. (2000) Imbricate structure of chert-clastic sequence of the Kuzu Complex in the Shiraiwa area of the Ashio belt, central Japan. The Memoirs of the Geological Society of Japan, no. 55, 203-221. (in Japanese with English abstract)

Kamata, Y. and Kajiwara, Y. (1996) Sulfur isotopic data from the Permian-Triassic boundary chert sequence at Motegi, Gunma Prefecture, in the Ashio terrane, central Japan. In Noda, H. and Sashida, K., Eds., Professor Hiroyoshi Igo Commemorative Volume on Geology and Paleontology of Japan and Southeast Asia., Gakujyutsu Tosho Insatsu Co. Ltd., Tokyo, Japan, 19-27.

Kamata, Y. and Mizobe, S. (2001) Co-occurrence of an Early Jurassic ammonite and Middle Jurassic radiolarians in the Kuzu Complex of the Ashio belt, central Japan and its stratigraphic bearing. News of Osaka Micropaleontologists (NOM), Special Volume, no. 12, 191-201. (in Japanese with English abstract)

Kamata, Y., Mizobe, S. and Sato, T. (2003) An Early Jurassic ammonite from a limestone conglomerate in the Kuzu Complex of the Ashio belt. Paleontological Research, 7, 185-194.

Kawata, K. and Ozawa, A. (1955) Explanatory text of the Geological map of Japan, Scale 1:50,000, Ashio. Geological Survey of Japan. 57p. (in Japanese with English Summary)

Kiessling, W. (1999) Late Jurassic radiolarians from the Antarctic Peninsula. Micropaleontology, 45 (supplement no. 1), 1-96.

Kiessling, W. Scasso, R. Zeiss, A., Riccardi, A. and Medina, F. (1999) Combined radiolarian-ammonite stratigraphy for the late Jurassic of the Antarctic Peninsula: Implications for radiolarian stratigraphy. Geodiversits, 21, 687-713.

Kobayashi, F. (1979) Petrography and sedimentary environment of the Permian nabeyama limestone in the Kuzu area, Tochigi Prefecture, central Japan. The Journal of the Geological Society of Japan, $\mathbf{8 5}$, 627-642. (in Japanese with English abstract)

Kobayashi, F. (2006a) Middle Permian fusulinaceans of the Izuru and Nabeyama formations in the Kuzu area, Tochigi Prefecture, Japan. Part 1. Schwagerinid, neoschwagerinid, and verbeekinid fusulinoideans. Paleontological Research, 10, 37-59.

Kobayashi, F. (2006b) Middle Permian foraminifers of the Izuru and Nabeyama formations in the Kuzu area, central Japan Part 2. Schubertellid and ozawainellid fusulinoideans, and non-fusulinoidean foraminifers. Paleontological Research, 10, 61-77.

Kobayashi, T. and Hamada, T. (1984) The Middle and Upper Permian Trilobites from the Akasaka Limestone in Gifu Prefecture, West Japan. Proceedings of the Japan Academy, Series B, Physical and Biological Sciences, 60, 1-4.

Koike, T., Watanabe, K. and Igo, Hh. (1970) New evidence of Triassic conodont biostratigraphy in Japan. The Journal of the Geological Society of Japan, 76, 267-269. (in Japanese with English abstract)

Koike, T., Kinoshita, T., Igo, Hh. and Takizawa, S. (1971) Conodonts from the Tochigi Group and the discovery of the thrust fault in the vicinity of Kuzuu, Tochigi Prefecture. The Journal of the Geological Society of Japan, 77, 221-222. (in Japanese with English abstract)

Koike, T., Igo, Hy., Igo, Hh. and Kinoshita, T. (1974) geological significance of the unconformity between the Permian Nabeyama and Triassic Adoyama formations in the vicinity of Kuzuu, Tochigi Prefecture. The Journal of the Geological Society of Japan, 80, 293-306. (in Japanese with English abstract)

Koike, T., Kodachi, Y., Matsuno, T. and Baba, H. (1991) Triassic conodonts from exotic blocks of limestone in northern Kuzuu, the Ashio Mountains. Science Reports of the Yokohama National University, Section II, Biological and Geological Sciences, no. 38, 53-69.

Koizumi, H., Yoshino, T. and Kojima, H. (1979) Occurrences of Permian trilobite Pseudophillipsis from Yamasuge, Kuzu Town, Tochigi Prefecture*. Earth Science (Chikyu Kagaku), 33, 353-354. (in Japanese)

Koizumi, H., Hayashi, S. and Tanaka, H. (1988) Occurrences of Permian trilobite Pseudophillipsis (s.s.) from the Kiriu area, Ashio Mountains, central Japan. Bulletin of the Gunma Prefectural Museum of History, 9, 99-109. (in Japanese)

Kojima, S., Hayasaka, Y., Hiroi, Y., Matsuoka, A., Sano, H., Sugamori, Y., Suzuki, N., Takemura, S., Tsujimori, T. and Uchino, T. (2016) Pre-Cretaceous accretionary complexes. In Moreno, T., Wallis, S. and Gibbons, W. eds., The Geology of Japan, Geological Society of London, London, 61-100.

Kozai, T., Ishida, K. and Kondo, Y. (2006) Radiolarians, 
bivalves and the $\mathrm{J} / \mathrm{K}$ boundary in the Birafu Formation, southern Kurosegawa belt, central Shikoku, SW Japan. Geosciences Journal, 10, 217-235.

Kozur, H. (1980) Ruzhencevispongidae, eine neue Spumellaria Familie ausdemoberen Kungurian (Leonardian) und Sakmarian des Vorurals. Geologisch Paläontologische Mitteilungen Innsbruck, 10, 235-242.

Kozur, H. (1984) New radiolarian taxa from the Triassic and Jurassic. Geologisch Paläontologische Mitteilungen Innsbruck, 13, 49-88.

Kozur, H. (1988) Muelleritortiidae n. fam., eine charakteristische longobardische (oberladinische) Radiolarienfamilie, Teil II. Freiberger Forschungshefte, C427, 95-100.

Kozur, H. and Mostler, H. (1979) Beiträge zur Erforschung der mesozoischen Radiolarien. Teil III: Die Oberfamilien Actinommacea Haeckel, 1862 emend., Artiscacea Haeckel, 1882, Multiarcusellacea nov. der Spumellaria und triassische Nassellaria. Geologisch Paläontologische Mitteilungen Innsbruck, 9, 1-132.

Kozur, H. and Mostler, H. (1981) Beiträge zur Erforschung der mesozoischen Radiolarien. Teil IV: Thalassosphaeracea Haeckel, 1862, Hexastylacea Haeckel, 1862 emend. Petrushevskaya, 1979, Sponguracea Haeckel, 1862 emend. und weitere triassische Lithocycliacea, Trematodiscacea, Actinommacea und Nassellaria. Geologisch Paläontologische Mitteilungen Innsbruck, 1, 1-208.

Kozur, H. and Mostler, H. (1982) Entactinaria Subordo nov., a new radiolarian suborder. Geologisch Paläontologische Mitteilungen Innsbruck, 11, 399-414.

Kozur, H. and Mostler, H. (1989) Radiolarien und schwammskleren aus dem Unterperm des Vorurals. Geologisch Paläontologische Mitteilungen Innsbruck, Sonderband, 2, 147-275.

Kozur, H. and Mostler, H. (1994). Anisian to Middle Carnian radiolarian zonation and description of some stratigraphically important radiolarians. GeologischPaläontologische Mitteilungen Innsbruck, 3, 39-255.

Kuwahara, K., Yao,A. and Yamakita, S. (1998) Reexamination of Upper Permian radiolarian biostratigraphy. Earth Science (Chikyu Kagaku), 52, 391-404.

Masuda, S. (1989) Jurassic radiolarian fossils in the Hachioji Hill. Research Reports, Ashikaga Institute of Technology, no. 15, 207-214. (in Japanese with English abstract)

Matsuda, T. and Isozaki, Y. (1991) Well-documented travel history of Mesozoic pelagic chert in Japan: from remote ocean to subduction zone. Tectonics, 10, 475-499.

Matsuoka, A. (1983) Middle and late Jurassic radiolarian biostratigraphy in the Sakawa and adjacent areas, Shikoku, Southwest Japan. Journal of Geosciences, Osaka City University, 26, 1-48.

Matsuoka, A. (1985) Middle Jurassic Keta Formation of the southern part of the Middle Chichibu terrane in the Sakawa area, Kochi Prefecture, Southwest Japan.
The Journal of the Geological Society of Japan, 91, 411-420. (in Japanese with English abstract)

Matsuoka, A. (1986) Faunal change of radiolarians around the Jurassic-Cretaceous boundary —with special reference to some multi-segmented nassellarians-. Fossils (Kaseki), no. 40, 1-15. (in Japanese with English abstract)

Matsuoka, A. (1988) First appearance biohorizon of Tricolocapsa conexa within Jurassic siliceous mudstone sequences of the Kamiaso area in the Mino terrane, central Japan-A correlation of radiolarian zones of the Middle Jurassic. The Journal of the Geological Society of Japan, 94, 583-590.

Matsuoka, A. (1991) Early Jurassic Radiolarians from the Nanjo Massif in the Mino terrane, central Japan. Part 1. Tricolocapsa, Stichocapsa, and Minocapsa, n. gen. Transactions and Proceedings of the Paleontological Society of Japan, New Series, no. 161, 720-738.

Matsuoka, A. (1995) Jurassic and Lower Cretaceous radiolarian zonation in Japan and in the Western Pacific. The Island Arc, 4, 140-153.

Matsuoka, A. and Ito, T. (2019) Updated radiolarian zonation for the Jurassic in Japan and the western Pacific. Science Reports of Niigata University (Geology), no. 34, 49-57.

Matsuoka, A. and Yao, A. (1986) A newly proposed radiolarian zonation for the Jurassic of Japan. Marine Micropaleontology, 11, 91-105.

Minato, M. (1951) Some Carboniferous corals from southwestern Japan. Transactions and Proceedings of the Paleontological Society of Japan, New Series, no. $1,1-5$.

Minato, M. (1955) Japanese Carboniferous and Permian corals. Journal of the Faculty of Science, Hokkaido University, Series 4, Geology and mineralogy, 9, 1-202.

Mizutani, S. and Kido, S. (1983) Radiolarians in the Middle Jurassic siliceous shale from Kamiaso, Gifu Prefecture, central Japan. Transactions and Proceedings of the Paleontological Society of Japan, New Series, no. 132, 253-262.

Morikawa, R. and Horiguchi, M. (1956) Parafusulina nakamigawai $\mathrm{n}$. sp. from the Adoyama Formation in the Neighborhood of Kuzu City, Tochigi Prefecture. Science Reports of the Saitama University, Series B (Biology and Earth Sciences), 2, 261-264.

Morikawa, R. and Takaoka, Y. (1961) Two New species of the Parafusulina yabei type from Tomura, Totigi Prefecture, central Japan. Transactions and Proceedings of the Palaeontological Society of Japan, New Series, no. 41, 33-40.

Motoki, H. and Sashida, K. (2004) Preliminary report on the chronological and lithostratigraphical studies of the Toishi-type shale (siliceous claystone) distributed in the Ashio Mountains, central Japan. News of Osaka Micropalaeontologists (NOM), Special Volume, no. 13, 47-57. (in Japanese with English abstract) 
Müller, J. (1858) Uber die Thalassicollen, Polycystinen und Acanthometren des Mittelmeeres. Konigliche Preussische Akademie der zu Berlin, Abhandlungen, Jahre, 1-62.

Muto, S. and Ito, T. (2021) Conodont fossils from the Kiryu and Ashikaga District (Quadrangle series 1:50,000), central Japan with emphasis on the reexamination of "Carboniferous" conodonts from the Ashio Belt. Bulletin of the Geological Survey of Japan, 72, 325-344.

Muto, S., Takahashi, S., Yamakita, S., Suzuki, N., Suzuki, N. and Aita, Y. (2018) High sediment input and possible oceanic anoxia in the pelagic Panthalassa during the latest Olenekian and early Anisian: Insights from a new deep-sea section in Ogama, Tochigi, Japan. Palaeogeography. Palaeoclimatology, Palaeoecology, 490, 687-707.

Muto, S., Okumura, Y. and Mizuhara, T. (2021) Late Kungurian conodonts of the pelagic Panthalassa from seamount-capping limestone in Ogama, Kuzuu, Tochigi Prefecture, Japan. Paleontological Research, 25, 105-119.

Nakae, S. (2000) Regional correlation of the Jurassic accretionary complex in the Inner Zone of Southwest Japan. The Memoirs of the Geological Society of Japan, no. 55, 73-98. (in Japanese with English abstract)

Nakaseko, K. and Nishimura, A. (1979) Upper Triassic Radiolaria from southwest Japan. Science Reports, College of General Education, Osaka University, 28, 61-109.

Nazarov, B. B. and Ormiston, A. R. (1983) A new superfamily of stauraxon polycystine Radiolaria from the Late Paleozoic of the Soviet Union and North America. Senckenbergiana Lethaea, 64, 363-379.

Nazarov, B. B. and Ormiston, A. R. (1984) Tentative system of Paleozoic Radiolaria, in Petrushevskaya, M. G. and Stepanjants, S. D. (eds), Morphology, Ecology and Evolution of Radiolarians. Material from the IV Symposium of European Radiolarists EURO-RAD IV. Academiya Nauk SSSR, Zoological Institute, Leningrad, USSR, 64-87.

Nazarov, B. B. and Ormiston, A. R. (1989) New radiolarian species from the Permian of Southern Urals and Nevada. Paleontological Journal, 23, 10-20.

Nestell, G. P. and Nestell, M. K. (2020) Roadian (earliest Guadalupian, Middle Permian) Radiolarians from the Guadalupe Mountains, West Texas, USA Part I: Albaillellaria and Entactinaria. Micropaleontology, 66, $1-50$.

Nicora, A. (1977) Lower Anisian platform-conodonts from the Tethys and Nevada: Taxonomic and stratigraphic revision. Palaeontographia Abteilung A, 157, 88-107.

Noble, P., Aitchison, J. C., Danelian, T., Dumitrica, P., Maletz, J., Suzuki, N., Cuvelier, J., Caridroit, M. and O’Dogherty, L. (2017) Taxonomy of Paleozoic radiolarian genera. Geodiversitas, 39, 419-502.

O’Dogherty, L. (1994) Biochronology and paleontology of mid-Cretaceous radiolarians from Northern Apennines (Italy) and Betic Cordillera (Spain). Mémoires de Géologie (Lausanne), 21, 1-415.

O’Dogherty, L., Bill, S., Goričan, Š., Dumitrica, P. and Masson, H. (2006) Bathonian radiolarians from an ophiolitic mélange of the Alpine Tethys (Gets Nappe, Swiss-French Alps). Micropaleontology, 51, 425-485.

O’Dogherty, L., Carter, E. S., Dumitrica, P., Goričan, Š., De Wever, P., Bandini, A. N., Baumgartner, P. O. and Matsuoka, A. (2009a) Catalogue of Mesozoic radiolarian genera. Part 2: Jurassic-Cretaceous. Geodiversitas, 31, 271-356.

O’Dogherty, L., Carter, E. S., Dumitrica, P., Goričan, Š., De Wever, P., Hungerbuhler, A., Bandini, A. N. and Takemura, A. (2009b) Catalogue of Mesozoic radiolarian genera. Part 1: Triassic. Geodiversitas, 31, 213-270.

O’Dogherty, L., Goričan, Š. And Gawlick, H. J. (2017) Middle and Late Jurassic radiolarians from the Neotethys suture in the Eastern Alps. Journal of Paleontology, 91, 25-72.

Ogg, J. G., Ogg, G. M. and Gradstein, F. M. (2016) A Concise Geologic Time Scale 2016. Elsevier, Amsterdam, 234p.

Ootaka, M., Aita, Y. and Sakai, T. (1998) Middle Triassic radiolarian biostratigraphy of the bedded chert in the Minowa quarry, Kuzuu Town, Ashio Mountains. News of Osaka Micropaleontologists (NOM), Special Volume, no. 11, 95-113.

Ormiston, A. R. and Babcock, L. (1979) Follicucullus, new radiolarian genus from the Guadalupian (Permian) Lamar limestone of the Delaware Basin. Journal of Paleontology, 53, 328-334.

Pessagno, E. A. (1976) Radiolarian zonation and stratigraphy of the Upper Cretaceous portion of the Great Valley Sequence, California Coast Ranges. Micropaleontology, Special Publication, 2, 1-95.

Pessagno, E. A. (1977a) Upper Jurassic Radiolaria and radiolarian biostratigraphy of the California Coast Ranges. Micropaleontology, 23, 56-113.

Pessagno, E. A. (1977b) Lower Cretaceous radiolarian biostratigraphy of the Great Valley sequence and Franciscan Complex, California Coast Ranges. Cushman Foundation for Foraminiferal Research, no. $15,5-87$.

Pessagno, E. A. and Blome, C. D. (1980) Upper Triassic and Jurassic Pantanelliinae from California, Oregon and British Columbia. Micropaleontology, 26, 225-273.

Pessagno, E. A. and Whalen P. (1982) Lower and Middle Jurassic Radiolaria (multicyrtid Nassellariina) from California, east-central Oregon and the Queen Charlotte Islands, B. C. Micropaleontology, 28, 111-169.

Reif, W. E. and Goto, M. (1979) Placoid scales from the Permian of Japan. Neues Jahrbuch für Geologie und 
Paläontologie, Monatshefte, 4, 201-207.

Riedel, W. R. (1967) Some new families of Radiolaria. Proceedings of the Geological Society of London, 1640, 148-149.

Rigo, M., Mazza, M., Karádi, V. and Nicora, A. (2018) New Upper Triassic conodont biozonation of the Tethyan Realm. In Tanner, L. H., Ed., The Late Triassic World, Topics of Geobiology, 46, 189-235.

Rüst, D. (1885) Beiträge zur Kenntniss der fossilen Radiolarien aus Gesteinen des Jura. Palaeontographica, 31, 269-321.

Rüst, D. (1892) Radiolaria from the Pierre Formation of North-Western Manitoba. Geological and Natural History Survey of Canada, Contributions to Canadian Micropalaeontology, 4, 101-110.

Saito, Y. and Kato, A. (1971) Smaller foraminifers from limestone lenses in the west of Umenoki, Kuzuu-machi Ashio Mountainland. The Journal of the Geological Society of Japan, 77, 675-676. (in Japanese)

Sanfilippo, A. and Riedel, W. R. (1970) Post-Eocene "closed" theoperid radiolarians. Micropaleontology, 16, 446-462.

Sashida, K. (2008) c. A geologic unit in the Hachioji Hills, which corresponds to the Ashio belt, 2.3.1. Paleozoic-Mesozoic in the Ashio Mountains, 2.3. Ashio Mountains*. In Geological Society of Japan (Eds.), Regional Geology of Japan, part 3, Kanto District*. Tokyo: Asakura Publishing, 99-100. (in Japanese)

Sashida, K., Igo, Hh., Igo, Hy., Takizawa, S., Hisada, K., Shibata, T., Tsukada, K. and Nishimura, H. (1982a) On the Jurassic radiolarian assemblages in the Kanto district. News of Osaka Micropaleontologists (NOM), Special Volume, no. 5, 51-66. (in Japanese with English abstract)

Sashida, K., Igo, Hy., Igo, Hh., Takizawa, S. and Hisada, K. (1982b) On the occurrence of Jurassic radiolarians from the Kanto Region and Hida Mountains, central Japan. Annual Report of Institute of Geosciences, University of Tsukuba, no. 8, 74-77.

Sashida, K., Kamata, Y. and Igo, H. (1992) "Toishi-type shale" in the Ashio Mountains, central Japan. Annual Report of the Institute of Geoscience, the University of Tsukuba, no. 18, 59-66.

Sudo, S., Makimoto, H., Hata, M., Unozawa, A., Takizawa, F. and Sakamoto, T. (1991) Geological map of the Utsunomiya district. Quadrangle Series, 1:200,000, Geological Survey of Japan.

Sugiyama, K. (1997). Triassic and Lower Jurassic radiolarian biostratigraphy in the siliceous claystone and bedded chert units of the southeastern Mino terrane, central Japan. Bulletin of the Mizunami Fossil Museum, 24, 79-193.

Suzuki, H. (1898a) Ashio Copper Mine*. Journal of Geography (Chigaku Zasshi), 10, 183-195. (in Japanese)

Suzuki, H. (1898b) An investigative report of the Ashio Copper Mine*. Journal of the Mining Institute of
Japan, 14, 318-324. (in Japanese)

Suzuki, N., Akiba, N. and Kanoh, H. (2002) Late Olenekian radiolarians from bedded chert of Ashio terrane, northeast Japan, and faunal turnovers in western Panthalassa during Early Triassic. Journal of China University of Geosciences, 13, 124-140.

Sykora, M., Ozvoldova, L. and Boorova, D. (1997) Turonian silicified sediments in the Czorsztyn succession of the Pieniny Klippen Belt (Western Carpathians, Slovakia). Geologica Carpathica, 48, 243-261.

Takakuwa, Y. (2021) Research on fossil Chondrichtyes I Japan: current status and future. Fossils (Kaseki), 109, 5-17. (in Japanese with English abstract)

Takakuwa, Y. and Okabe, I. (2011) New occurrence of ctenacanthid sharks from the Permian of the Ashio tectonic belt, Kiryu City, Gunma Prefecture, central Japan. Bulletin of Gunma Museum of Natural History, 15, 153-159. (in Japanese with English abstract)

Takayanagi, A., Hori, N. and Sashida, K. (2001) Tectonostratigraphy of sedimentary complex of the Ashio terrane in the northern part of the Ashikaga area, Tochigi Prefecture, and the occurrence of radiolarians. News of Osaka Micropaleontologists (NOM), Special Volume, no. 12, 113-127. (in Japanese with English abstract)

Takemura, A. (1986) Classification of Jurassic Nassellarians (Radiolaria). Palaeontographica. Abteilung A: Palaozoologie-Stratigraphie, 195, 29-74.

Takemura, A. and Ling, H. Y. (1998) Taxonomy and phylogeny of the genus Theocorys (Nassellaria, Radiolaria) from the Eocene and Oligocene sequences in the Antarctic region. Paleontological Research, 2, $155-169$.

Tazawa, J. and Takakuwa, Y. (2009) Eolyttonia (Lyttonioidea, Brachiopoda) from Kiryu, central Japan. Bulletin of Gunma Museum of Natural History, 13, 29-33.

Tazawa, J., Hayashi, S., Nakamura, K., Shimizu, M. and Takakuwa, Y. (2012) Early Permian brachiopods from Kiryu, Ashio belt, central Japan. Bulletin of Gunma Museum of Natural History, 16, 41-48.

Tazawa, J., Okumura, Y., Miyake, Y. and Mizuhara, T. (2016) A Kungurian (early Permian) brachiopod Fauna from Ogama, Kuzu area, central Japan, and its palaeobiogeographical affinity with the WolfcampianLeonardian (early Permian) brachiopod fauna of West Texas, USA. Paleontological Research, 20, 367-384.

Tekin, U, K. (1999) Biostratigraphy and systematics of late Middle to Late Triassic radiolarians from the Taurus Mountains and Ankara region, Turkey. Geologisch Paläontologische Mitteilungen Innsbruck, Sonderband, 5, 1-296.

Wakita, K. (2015) OPS mélange: a new term for mélanges of convergent margins of the world. International Geology Review, 57, 529-539.

Wakita, K. and Metcalfe, I. (2005) Ocean Plate Stratigraphy 
in East and Southeast Asia. Journal of Asian Earth Science, 24, 679-702.

Won, M. Z. (1983) Radiolarien aus dem Unterkarbon des Rheinischen Schiefergebirges (Deutschland). Palaeontographica. Abteilung A: PaleozoologieStratigraphie, 182, 116-175.

Xiao, Y. F., Suzuki, N. and He, W. H. (2018) Low-latitudinal standard Permian radiolarian biostratigraphy for multiple purposes with Unitary Association, Graphic Correlation, and Bayesian inference methods. EarthScience Reviews, 179, 168-206.

Xiao. Y. F., Suzuki, N., He, W. H., Benton, M. J. and Yang, T. L. (2020) Verifiability principle of genus-level classification under quantification and parsimony theories: a case study of follicucullid radiolarians. Paleobiology, 46, 337-355.

Xiao. Y. F., Suzuki, N., Ito, T. and He, W. H. (2021) New Permian radiolarians from east Asia and the quantitative reconstruction of their evolutionary and ecological significances. Scientific Reports, 11, 6831.

Yabe, H. (1899) About fusulina in Tomuro*. The Journal of the Geological Society of Japan, 6, 189-194. (in Japanese)

Yabe, H. (1903) A fusulina-limestone with Helicoprion in Japan. The Journal of the Geological Society of Japan, 10, 1-13.

Yamagiwa, N. and Tsuda, H. (1980) A new coral species from a pebble in the basal limestone conglomerate of the Triassic Adoyama Formation at Karasawa in the Kuzu area, Tochigi Prefecture, Japan. Bulletin of the National Science Museum, Series C, Geology and Paleontology, 6, 251-257.

Yanagimoto, Y. (1973) Stratigraphy and geological structure of the Paleozoic and Mesozoic formations in the vicinity of Kuzuu, Tochigi Prefecture. The Journal of the Geological Society of Japan, 79, 441-451. (in Japanese with English abstract)

Yang, Q. (1993) Taxonomic studies of Upper Jurassic (Tithonian) radiolaria from the Taman Formation, east-central Mexico. Palaeoworld, no. 3, 1-164.

Yao, A. (1979) Radiolarian fauna from the Mino belt in the northern part of the Inuyama Area, central Japan, Part II: Nassellaria 1. Journal of Geosciences, Osaka
City University, 22, 21-72.

Yao, A. (1982) Middle Triassic to Early Jurassic radiolarians from the Inuyama area, central Japan. Journal of Geosciences, Osaka City University, 25, 53-70.

Yao, A. (1997) Faunal change of Early-Middle Jurassic radiolarians. News of Osaka Micropalaeontologists (NOM), Special Volume, no. 10, 155-182. (in Japanese with English abstract)

Yao, A., Matsuoka, A. and Nakatani, T. (1982) Triassic and Jurassic radiolarian assemblages in Southwest Japan. News of Osaka Micropaleontologists (NOM), Special Volume, no. 5, 27-43. (in Japanese with English abstract)

Yoshida, H. (1986) Upper Triassic to Lower Jurassic radiolarian biostratigraphy in Kagamigahara City, Gifu Prefecture, central Japan. The Journal of earth sciences, Nagoya University, 34, 1-21.

Yoshida, S. (1956) Stratigraphical and tectonical studies in the distinct neighboring Kuzuu Machi, Tochigi Prefecture, Part 1. Bulletin of the Geological Committee of Hokkaido, no. 32, 1-10. (in Japanese with English abstract)

Yoshida, S. (1957) Stratigraphical and tectonical studies in the distinct neighboring Kuzuu Machi, Tochigi Prefecture, Part 2. Bulletin of the Geological Committee of Hokkaido, no. 33, 1-15. (in Japanese with English abstract)

Zhang, L., Ito, T., Feng, Q. L., Caridroit, M. and Danelian, T. (2014) Phylogenetic model of Follicucullus lineages (Albaillellaria, Radiolaria) based on high-resolution biostratigraphy of the Permian Bancheng Formation, Guangxi, South China. Journal of Micropaleontology, 33, 179-192.

Zhang, Y. C. and Wang, Y. (2018) Permian fusuline biostratigraphy. In Lucas, S. G. and Shen, S. Z., Eds., The Permian Time Scale, Geological Society, London, Special Publication, 450, 253-288.

*Translated by the author

Recieved June 29, 2020

Accepted July 9, 2021 


\section{5 万分の 1 地質図幅「桐生及足利」地域の足尾帯ジュラ紀付加体から産出した放散虫}

\section{伊藤 剛}

\section{要 旨}

足尾山地には足尾帯ジュラ紀付加体が分布する. このジュラ紀付加体は, 黒保根一桐生コンプレックス・大間々コン プレックス・葛生コンプレックス・行道山コンプレックスの 4 コンプレックスからなる. 本論では, 5 万分の 1 地質図幅 「桐生及足利」地域の足尾帯ジュラ紀付加体の 42 試料から新たに産出した放散虫について報告する。ペルム紀放散虫は, 行道山コンプレックスのチャート 9 試料から産出した。 三助紀放散虫は，葛生コンプレックスのチャート 4 試料から産 出した。 また，ジュラ紀放散虫は，黒保根－桐生コンプレックスの珪質泥岩 1 試料, 暮生コンプレックスのチャート 2 試料, 葛生コンプレックスの珪質泥岩 4 試料, 葛生コンプレックスの泥岩 2 試料及び行道山コンプレックスの泥岩 1 試 料から産出した. 加えて, 足尾山地ジュラ紀付加体におけるこれまでの化石産出とその年代についてとりまとめた。 こ れらを踏まえ, 各コンプレックスの海洋プレート層序を復元した。 